\title{
Forum Non Conveniens and Retaliatory Legislation: The Impact on the Available Alternative Forum Inquiry and on the Desirability of Forum Non Conveniens as a Defense Tactic
}

\author{
Walter W. Heiser ${ }^{*}$
}

\section{INTRODUCTION}

A motion to dismiss on grounds of forum non conveniens has become the primary response of domestic defendants to tort actions brought by foreign plaintiffs in U.S. courts. ${ }^{1}$ The motion is not only filed, but also granted, in nearly every case. ${ }^{2}$ Various elements of the modern doctrine of forum non conveniens almost guarantee this outcome where the alleged wrongful act and injury occurred in another country. ${ }^{3}$ A forum non conveniens dismissal typically means that a foreign plaintiff must seek relief in the courts of his own country. As a result, a foreign plaintiff will likely recover much less than a domestic plaintiff injured by a domestic company. ${ }^{4}$ The various procedural and substantive

\footnotetext{
Professor of Law, University of San Diego School of Law. B.A., University of Michigan, 1968; J.D., University of Wisconsin, 1971; LL.M., Harvard University, 1978.

1. See, e.g., Sheila L. Birnbaum \& Douglas W. Dunham, Foreign Plaintiffs and Forum Non Conveniens, 16 BrooK. J. INT'L L. 241, 243 (1990); Daniel J. Dorward, Comment, The Forum Non Conveniens Doctrine and the Judicial Protection of Multinational Corporations from Forum Shopping Plaintiffs, 19 U. PA. J. INT'L ECON. L. 141, 161 (1998); Douglas W. Dunham \& Eric F. Gladbach, Forum Non Conveniens and Foreign Plaintiffs in the 1990s, 24 BROOK. J. INT'L L. 665, 673 (1999); William L. Reynolds, The Proper Forum for Suit: Transnational Forum Non Conveniens and Counter-Suit Injunctions in the Federal Courts, 70 TEX. L. REV. 1663, 1664-65 (1992); Russell J. Weintraub, International Litigation and Forum Non Conveniens, 29 TEX. INT'L L.J. 321, 322 (1994) [hereinafter Weintraub, International Litigation].

2. See infra notes 60-63 and accompanying text.

3. See infra notes $12-63$ and accompanying text.

4. See Laurel E. Miller, Comment, Forum Non Conveniens and State Control of Foreign Plaintiff Access to U.S. Courts in International Tort Actions, 58 U. CHI. L. REV. 1369, 1388 (1991) (explaining that "few cases dismissed... on forum non conveniens grounds ever reach trial abroad"); David W. Robertson, Forum Non Conveniens in America and England: "A Rather Fantastic Fiction," 103 L.Q. REV. 398, 418-20 (1987) (discussing an informal survey of dismissed cases which indicates the majority of foreign plaintiffs decided not to sue in the alternative forums, or settled for small amounts); Weintraub, International Litigation, supra note 1, at 335 (observing that "faced with higher costs and lower returns abroad," it is hardly surprising that "the vast majority of foreign plaintiffs decide[] not to sue or settle[] for a fraction of the claim's "estimated value""
} 
advantages that make suit in the United States so attractive to a foreign plaintiff may not exist in the courts of that plaintiff's country, making litigation there uneconomical and impractical. ${ }^{5}$ Consequently, after a forum non conveniens dismissal, a foreign plaintiff often settles for a small amount or simply forgoes his claims altogether. ${ }^{6}$

Until recently, other countries have done little to counter forum non conveniens dismissals. That acquiescence, however, is in the process of changing. Several countries in Latin America have enacted statutes specifically designed to counter dismissals of transnational tort actions brought by their citizens in U.S. courts against U.S. defendants. ${ }^{7}$ If these legislative efforts are successful, other countries are likely to follow suit.

This retaliatory legislation has taken one of two forms. Some countries have adopted limits on jurisdiction that apparently preclude their courts from hearing any action by one of their residents that was previously commenced in another country, but dismissed based on forum non conveniens. ${ }^{8}$ Although this legislation often refers generically to cases where the plaintiff resorts to his country's courts "due to the declinature of foreign judges" who had jurisdiction, there is little doubt that these blocking statutes are intended specifically to prevent courts in the United States from finding that an alternative forum is "available" to hear the plaintiff's lawsuit. ${ }^{9}$

Other countries have adopted statutes that, at a minimum, authorize their courts to apply tort liability and damages law similar to that of the country in which an action was previously commenced by one of their residents, but subsequently dismissed on forum non conveniens. ${ }^{10}$ The

after a dismissal).

5. See Henry Saint Dahl, Forum Non Conveniens, Latin America and Blocking Statutes, 35 U. MiAmi INTER-AM. L. REV. 21, 37-42 (2004) (explaining the impracticality of litigation in most Latin American countries); Dante Figueroa, Conflicts of Jurisdiction Between the United States and Latin America in the Context of Forum Non Conveniens Dismissals, 37 U. MiAmi InTER-AM. L. Rev. 119 , 143-50 (2005) (discussing the inadequacies of many Latin American judicial systems with respect to civil litigation); Manuel A. Gómez, Like Migratory Birds: Latin American Claimants in U.S. Courts and the Ford-Firestone Rollover Litigation, 11 Sw. J. L. \& TRADE AM. 281, 295-97 (2005) (examining various reasons why Latin American plaintiffs prefer to litigate in U.S. courts).

6. See supra note 4.

7. See infra note 78 .

8. See infra notes $83-88$ and accompanying text.

9. See Dahl, supra note 5, at 21-24 \& app. 58-59; Figueroa, supra note 5, at 153-61.

10. These countries include Nicaragua and the Commonwealth of Dominica. See Winston Anderson, Forum Non Conveniens Checkmated?-The Emergence of Retaliatory Legislation, $10 \mathrm{~J}$. TRANSNAT'L L. \& POL'Y 183, 187-213 (2001) (analyzing Dominica's statutes); Paul Santoyo, Bananas of Wrath: How Nicaragua May Have Dealt Forum Non Conveniens a Fatal Blow Removing the Doctrine as an Obstacle to Achieving Corporate Accountability, 27 HOUS. J. INT'L L. 703, $723-36$ (2005) (discussing the Nicaraguan statutes); Dahl, supra note 5, at 50-53 (reproducing an English translation of the Nicaraguan statutes). 
intent behind these statutes is to make tort litigation in the courts of these countries no more attractive to U.S. defendants than tort litigation in U.S. courts. ${ }^{11}$

This Article examines the impact of both types of retaliatory legislation on the use of forum non conveniens. Part II discusses forum non conveniens generally, with emphasis on the threshold requirement that an alternative forum be both "available" and "adequate" to adjudicate the plaintiff's claims. The discussion here also explores why forum non conveniens is so important to U.S. defendants in transnational tort actions. Part III examines the two types of retaliatory legislation enacted by foreign countries to counter forum non conveniens dismissals. With respect to the preemptive jurisdiction legislation enacted by several countries, the discussion also addresses the important question of whether the existence of a blocking statute means that the courts in those countries are not "available" as an alternative forum. Part IV discusses the impact of statutes that import U.S.-style tort liability and damages law into the foreign litigation. The analytical focus here is on whether a judgment rendered by a foreign court pursuant to such legislation will be enforced in U.S. courts. Finally, Part V offers some final observations regarding the Latin American statutes and concludes that they may have a profound effect on the use of forum non conveniens as a defense tactic.

\section{FORUM NON CONVENIENS}

\section{A. The Doctrine of Forum Non Conveniens}

Forum non conveniens permits a trial court to dismiss a case where an alternative forum is available in another country and is substantially more convenient for the parties, the witnesses, or the court. ${ }^{12}$ The doctrine varies somewhat from state to state, but most jurisdictions have adopted an approach similar to that set forth by the Supreme Court in Gulf Oil Corp. v. Gilbert. ${ }^{13}$ A defendant filing a forum non conveniens

11. Santoyo, supra note 10 , at 727-29.

12. E.g., Piper Aircraft Co. v. Reyno, 454 U.S. 235, 241 (1981); Stangvik v. Shiley Inc., 819 P.2d 14, 17 (Cal. 1991). Much of this general discussion of forum non conveniens has been stated elsewhere. See Walter W. Heiser, Forum Non Conveniens and Choice of Law: The Impact of Applying Foreign Law in Transnational Tort Actions, 51 WAYNE L. REV. 1161, 1165-68 (2005).

13. 330 U.S. 501 (1947). Gilbert dealt with the federal common law doctrine of forum non conveniens in federal courts. Most states, by statute or by case law, have incorporated Gilbert's private and public interest factors into their forum non conveniens doctrine. See Martin Davies, Time to Change the Federal Forum Non Conveniens Analysis, 77 TUL. L. REV. 309, 315-16 (2002) (collecting cases); David W. Robertson \& Paula K. Speck, Access to State Courts in Transnational Personal Injury Cases: Forum Non Conveniens and Antisuit Injunctions, 68 TEX. L. REV. 937, 948- 
motion seeks dismissal of the action not because the chosen forum lacks jurisdiction-most transnational tort actions are filed in the state where the defendant resides - but because there is an alternative forum in another country which also has jurisdiction and, in addition, is far more convenient. ${ }^{14}$

In assessing whether a forum non conveniens dismissal is appropriate, a court must first determine whether an adequate alternative forum is available. ${ }^{15}$ Generally, a forum is considered adequate and available if the defendant is subject to personal jurisdiction there and no other procedural bar, such as the statute of limitations, prevents resolution of the merits in the alternative forum. ${ }^{16}$ The possibility of an unfavorable change in substantive or procedural law is ordinarily not a consideration relevant to the forum non conveniens analysis, unless the remedy provided by the alternative forum is "so clearly inadequate or unsatisfactory that it is no remedy at all."17

If a court determines that an adequate alternative forum is available, the court must then balance a variety of private and public interests associated with the litigation. As identified in Gilbert, the factors pertaining to the private interests of the litigants include "the relative ease of access to ... proof," "availability of compulsory process" for attendance of witnesses, the possibility of view of premises when appropriate to the action, "and all other practical problems that make a trial of a case easy, expeditious, and inexpensive."18 Questions as to the enforceability of any judgment rendered by the foreign tribunal also may be a relevant consideration. ${ }^{19}$

The public interest factors identified in Gilbert include the administrative difficulties for courts "when litigation is piled up in congested centers instead of being handled at its origin," the local interest in having localized controversies decided at home, the interest in having the trial in a forum that is at home with the law that must govern the action, the burden of jury duty imposed upon the citizens of a community that has no relation to the litigation, and the avoidance of unnecessary problems in conflicts of law or in the application of

53 (1990) (collecting authorities).

14. Gilbert, 330 U.S. at 506-09. See also Piper Aircraft, 454 U.S. at 249-56 (stating that convenience is "the central purpose of any forum non conveniens inquiry").

15. Piper Aircraft, 454 U.S. at 255 n.22; Stangvik, 819 P.2d at 17.

16. Piper Aircraft, 454 U.S. at 255 n.22; Stangvik, 819 P.2d at 18.

17. Piper Aircraft, 454 U.S. at 254; Stangvik, 819 P.2d at 19.

18. Gilbert, 330 U.S. at 508.

19. Id. 
unfamiliar foreign law. ${ }^{20}$ These public and private interest factors are to be applied flexibly by the courts, without giving undue emphasis to any one element. ${ }^{21}$ The balancing of these factors, as well as the ultimate determination of whether to grant or deny the forum non conveniens motion, is typically committed to the trial court's discretion. ${ }^{22}$

Although the stated purpose of forum non conveniens is to ensure that litigation occurs in the most appropriate forum, convenience has little to do with why a defendant seeks a forum non conveniens dismissal. ${ }^{23}$ The real reason is to force the plaintiff to re-file the lawsuit in another country, one whose substantive and procedural laws, and litigation culture, are more favorable to the defendant. ${ }^{24}$ Most courts do not question the propriety of this reverse forum shopping. ${ }^{25}$

Where the plaintiff is a resident of the forum state, there is ordinarily a strong presumption in favor of a plaintiff's choice of forum which may be overcome only when the private and public interest factors clearly point toward trial in the alternative forum. ${ }^{26}$ However, this presumption disappears when the plaintiff is a resident of a foreign country. ${ }^{27} \mathrm{~A}$ nonresident plaintiff's choice of forum is accorded little deference because that choice is viewed as based on choice of law considerations, not on convenience. ${ }^{28}$ Consequently, a foreign plaintiff's choice of a

20. Gilbert, 330 U.S. at 509; Piper Aircraft, 454 U.S. at 241 n.6.

21. Piper Aircraft, 454 U.S. at 249-50; Stangvik, 819 P.2d at 18-19.

22. Piper Aircraft, 454 U.S. at 257; Gilbert, 330 U.S. at 508-09; Stangvik, 819 P.2d at 17.

23. The parties in a transnational tort action often are arguing against their own conveniencethe foreign plaintiff wishing to litigate in the U.S. and the domestic defendant moving to have the case heard abroad. Reynolds, supra note 1, at 1672; Linda J. Silberman, Developments in Jurisdiction and Forum Non Conveniens in International Litigation: Thoughts on Reform and a Proposal for a Uniform Standard, 28 TEX. INT'L L.J. 501, 525-26 (1993) [hereinafter Silberman, Developments]; Allan R. Stein, Forum Non Conveniens and the Redundancy of Court-Access Doctrine, 133 U. PA. L. REV. 781, 784 (1985).

24. See Reynolds, supra note 1, at 1669-71; Silberman, Developments, supra note 23, at 525; Davies, supra note 13, at 316; Friedrich K. Juenger, Forum Shopping, Domestic and International, 63 Tul. L. ReV. 553, 563-64 (1989); David Boyce, Note, Foreign Plaintiffs and Forum Non Conveniens: Going Beyond Reyno, 64 TEX. L. REV. 193, 215-16 (1985).

25. See Piper Aircraft, 454 U.S. at $252 \mathrm{n} .19$ (noting where trial is unnecessarily burdensome, dismissal is appropriate regardless of the fact that the defendant may be motivated by a desire to obtain a more favorable forum); Stangvik, 819 P.2d at 25 (recognizing the defendant, as well as the plaintiff, is motivated by the desire to litigate in the most advantageous forum with respect to tort recovery).

26. Piper Aircraft, 454 U.S. at 255

27. Id. at 256; Stangvik, 819 P.2d at 20.

28. Piper Aircraft, 454 U.S. at 251-52. See Iragorri v. United Tech. Corp., 274 F.3d 65, 72 (2d Cir. 2001) (en banc) (ruling "the more it appears that the plaintiff's choice of a U.S. forum was motivated by forum-shopping reasons ... the less deference the plaintiff's choice commands"). 
U.S. forum is rarely a significant factor in favor of retaining jurisdiction. $^{29}$

\section{B. Threshold Requirements: An "Adequate" Alternative Forum Must Be "Available"}

The doctrine of forum non conveniens presupposes at least two fora where the defendant is amenable to suit, and simply furnishes criteria for choosing between them. ${ }^{30}$ In assessing whether a forum non conveniens dismissal is appropriate, a court must first determine whether an alternative forum that is both "available" and "adequate" exists. ${ }^{31}$ This is a two-part inquiry. Under the traditional doctrine, the motion must be denied if, for example, the alternative forum is deemed adequate but not available. $^{32}$ In most jurisdictions, the defendant, as the moving party, bears the burden of persuasion with respect to all elements of the forum non conveniens analysis, including the existence of an alternative forum that is both available and adequate. ${ }^{33}$

\section{The "Available" Alternative Forum Prerequisite}

A foreign forum is prima facie "available" if the defendant is subject to personal jurisdiction there and no other procedural bar, such as the statute of limitations, prevents resolution of the merits in the alternative forum. ${ }^{34}$ Until recently, this available alternative forum prerequisite rarely prevented a U.S. court from granting a forum non conveniens motion. ${ }^{35}$ Defendants routinely stipulate that they will waive any

29. See, e.g., Piper Aircraft, 454 U.S. at 255-56; Stangvik, 819 P.2d at 20. See Reynolds, supra note 1 , at $1691 \mathrm{n} .186$ (collecting authorities).

30. Gulf Oil Corp. v. Gilbert, 330 U.S. 501, 506-07 (1947); In re Bridgestone/Firestone, Inc., 420 F.3d 702, 703 (7th Cir. 2005); Dickson Marine Inc. v. Panalpina, Inc., 179 F.3d 331, 341 (5th Cir. 1999).

31. See, e.g., McLennan v. Am. Eurocopter Corp., 245 F.3d 403, 424 (5th Cir. 2001); Norex Petroleum, Ltd. v. Access Indus., 416 F.3d 146, 157-60 (2d Cir. 2005). See also Piper Aircraft, 454 U.S. at 255 n.22; Stangvik, 819 P.2d at 17.

32. See, e.g., Vasquez v. Bridgestone/Firestone, Inc., 325 F.3d 665, 671 (5th Cir. 2003); Kamel v. Hill-Rom Co., 108 F.3d 799, 803 (7th Cir. 1997); Norex, 416 F.3d at 157-60.

33. See, e.g., McLennan, 245 F.3d at 424; Leon v. Millon Air, Inc., 251 F.3d 1305, 1311 (11th Cir. 2001); Stangvik, 819 P.2d at 18.

34. Piper Aircraft, 454 U.S. at 255 n.22; Gilbert, 330 U.S. at 506-07; Kamel, 108 F.3d at 803; McLennan, 245 F.3d at 424; Stangvik, 819 P.2d at 18.

35. See Heiser, supra note 12, at 1169-74 (discussing cases); Megan Waples, Note, The Adequate Alternative Forum Analysis in Forum Non Conveniens: A Case for Reform, 36 ConN. L. REV. 1475, 1501 (2004) (reviewing cases and concluding foreign plaintiffs have very little success defeating a forum non conveniens motion on the basis of the adequacy of the alternative forum); 
objections to the alternative forum based on personal jurisdiction, service of process, or statute of limitations, rendering these considerations nonfactors. ${ }^{36}$ Likewise, trial courts typically make these waivers a condition of the forum non conveniens dismissal. ${ }^{37}$ Moreover, because an alternative forum deemed available may in fact turn out to be unavailable, courts often include a return jurisdiction clause in their dismissal orders that permits the parties to return to the dismissing court should the lawsuit become impossible in the foreign forum. ${ }^{38}$

\section{The "Adequate" Alternative Forum Prerequisite}

"A foreign forum is 'adequate' when the parties will not be deprived of all remedies or treated unfairly, even though they may not enjoy the same benefits as they might receive in an American court." ${ }^{39}$ The possibility of an unfavorable change in substantive or procedural law is ordinarily not a consideration relevant to the forum non conveniens analysis unless the remedy provided by the alternative forum is "so clearly inadequate or unsatisfactory that it is no remedy at all."

John R. Wilson, Note, Coming to America to File Suit: Foreign Plaintiffs and the Forum Non Conveniens Barrier in Transnational Litigation, 65 OHІо ST. L.J. 659, 682 (collecting cases).

36. See, e.g., Piper Aircraft, 454 U.S. at 242; In re Union Carbide Corp. Gas Plant Disaster at Bhopal, 634 F. Supp. 842 (S.D.N.Y. 1986), aff'd, 809 F.2d 195 (2d Cir. 1987); Stangvik, 819 P.2d at 18.

37. See, e.g., In re Silicone Gel Breast Implants Prod. Liab. Litig., 887 F. Supp. 1469, 1478-79 (N.D. Ala. 1995); Bhopal, 634 F. Supp. at 867; Stangvik, 819 P.2d at 17 n.2. See also John Bies, Note, Conditioning Forum Non Conveniens, 67 U. CHI. L. REV. 489, 501-03 nn.54-57 (2000) (collecting cases); Tim A. Thomas, Annotation, Validity and Propriety of Conditions Imposed Upon Proceedings in Foreign Forum by Federal Court in Dismissing Action Under Forum Non Conveniens, 89 A.L.R. FED. 238, 244-62 (1988 \& Supp. 2007-08) (collecting cases).

38. See, e.g., Vasquez v. Bridgestone/Firestone, Inc., 325 F.3d 665, 675 (5th Cir. 2003) (ruling trial court's "'failure to include a return jurisdiction clause in a [forum non conveniens] dismissal constitutes a per se abuse of discretion"') (quoting Robinson v. TCI/US W. Commc'ns, Inc., 117 F.3d 900, 907-08 (5th Cir. 1997); Lisa, S.A. v. Mayorga, 441 F. Supp. 2d 1233, 1241 (S.D. Fla. 2006); Delgado v. Shell Oil Co., 890 F. Supp. 1324, 1375 (S.D. Tex. 1995), aff'd, 231 F.3d 165 (5th Cir. 2000).

39. McLennan, 245 F.3d at 424 (quoting Alpine View Co. v. Atlas Copco AB, 205 F.3d 208, 221 (5th Cir. 2000)); see also Lueck v. Sundstrand Corp., 236 F.3d 1137, 1143-45 (9th Cir. 2001) (holding New Zealand accident compensation system provides an adequate remedy despite significant limitations on compensatory damages); DiRienzo v. Philip Servs. Corp., 232 F.3d 49, 57 (2d Cir. 2000) (collecting cases), vacated in part on other grounds, 294 F.3d 21 (2d Cir. 2002); PT United Can Co. v. Crown Cork \& Seal Co., 138 F.3d 65, 74 (2d Cir. 1998) (holding "[t]he availability of an adequate alternate forum does not depend on the existence of the identical cause of action in the other forum"); Waples, supra note 35, at 1484 n.50 (collecting cases). An alternative forum is also inadequate if the claimants cannot pursue their case in that forum without risking physical harm. See Mujica v. Occidental Petroleum Corp., 381 F. Supp. 2d 1134, 1142-45 (C.D. Cal. 2005) (collecting cases).

40. Piper Aircraft, 454 U.S. at 254. 
Arguments that an alternative forum is inadequate due to procedural deficiencies in the court system are rarely successful. ${ }^{41}$ Courts in the United States are hesitant to label the court system of another country procedurally "inadequate." 42 Only where that system is specifically proven to be corrupt or biased, and incapable of acting impartially with respect to the plaintiff's claims, will a court find an alternative forum inadequate. ${ }^{43}$ Where the alternative forum's court system is not corrupt or biased but procedurally underdeveloped, courts typically conclude that the lack of "beneficial litigation procedures similar to those available in U.S. courts does not render the alternative forum inadequate.",44 Moreover, defendants readily consent to a host of conditions designed to mitigate the adverse effects of any gross procedural deficiencies. ${ }^{45}$

41. Dunham \& Gladbach, supra note 1 at 675-78 (reviewing cases); Heiser, supra note 12 , at 1169-71 (discussing cases); C. Ryan Reetz \& Pedro J. Martinez-Fraga, Forum Non Conveniens and the Foreign Forum: A Defense Perspective, 35 U. Miami InTER-AM. L. ReV. 1, 8-10 (2003) (reviewing cases); Waples, supra note 35, at 1484-1504 (reviewing cases); see also Bhopal, $634 \mathrm{~F}$. Supp. 842, 845-67 (finding India an adequate alternative forum to hear mass tort actions despite evidence of such problems as chronic delay and backlog in Indian courts, inadequate pretrial discovery, undeveloped tort law, the Indian courts' and bars' lack of capacity to handle complex tort litigation, unavailability of class action procedures and contingent fees, and problems with enforcement of judgments).

42. See, e.g., PT United, 138 F.3d at 73 (observing that a finding of inadequacy is rare because "considerations of comity preclude a court from adversely judging the quality of a foreign justice system"); Chesley v. Union Carbide Corp., 927 F.2d 60, 66 (2d Cir. 1991) (observing “"[i]t is not the business of our courts to assume the responsibility for supervising the integrity of the judicial system of another sovereign nation"') (quoting Jhirad v. Fernandina, 536 F.2d 478, 484-85 (2d Cir. 1976); Reetz \& Martinez-Fraga, supra note 41, at 8-10 nn.32-50 (reviewing cases and concluding "this reluctance is based . . . on considerations of comity and respect for other nations' sovereignty").

43. See, e.g., Martinez v. Dow Chem. Co., 219 F. Supp. 2d 719, 737-38, 740-41 (E.D. La. 2002); Eastman Kodak Co. v. Kavlin, 978 F. Supp. 1078, 1085-87 (S.D. Fla. 1997); Waples, supra note 35, at 1497-99, 1502-03. General allegations of corruption and bias are insufficient. See, e.g., Aguinda v. Texaco, Inc., 303 F.3d 470, 478 (2d Cir. 2002); Stalinsky v. Bakoczy, 41 F. Supp. 2d 755, 759-62 (S.D. Ohio 1998) (collecting cases); Waples, supra note 35 at 1502-03.

44. See, e.g., Aguinda, 303 F.3d at 477-79; Satz v. McDonnell Douglas Corp., 244 F.3d 1279, 1283 (11th Cir. 2001) (quoting Borden, Inc. v. Meiji Milk Prods. Co., 919 F.2d 822, 829 (2d Cir. 1990)); Delgado v. Shell Oil Co., 890 F. Supp. 1324 (S.D. Tex. 1995), aff'd, 231 F.2d 165 (5th Cir. 2000). See Dunham \& Gladbach, supra note 1, at 675-78 (reviewing cases); Reetz \& MartinezFraga, supra note 41, at 9 (collecting cases); Waples, supra note 35, at 1485-1501 (reviewing cases).

45. See, e.g., Satz, 244 F.3d at 1283 (conditioning dismissal on defendant's agreement to pay any Argentine judgment against it, "to conduct all discovery in accordance with the Federal Rules of Civil Procedure, and [to] voluntarily produc[e] documents and witnesses within the United States"); Silicone Gel, 887 F. Supp. at 1478-79 (conditioning dismissal on defendants' submission to jurisdiction in various alternative forums, acceptance of service of process, waiver of limitations defenses, and agreements to pay final judgments); In re Union Carbide Corp. Gas Plant Disaster at Bhopal, 634 F. Supp. 842, 867 (S.D.N.Y. 1986) (conditioning dismissal on defendant's consent to jurisdiction in the courts of India, waiver of any statute of limitations defenses, compliance with the discovery rules of the Federal Rules of Civil Procedure, and agreement to satisfy any judgment); Stangvik, 819 P.2d 14, 17 n.2 (defendants agreed to submit to jurisdiction in the Scandinavian courts, toll the statute of limitations, "make documents in their possession available for inspection in Sweden and Norway ... a defendants' expense," permit depositions to proceed in accordance with 
One aspect of "adequacy" is whether a foreign plaintiff will be able to enforce a judgment obtained through his national courts. ${ }^{46}$ The plaintiff's concern here is whether the U.S. defendant has assets in the foreign country sufficient to satisfy a judgment rendered by a court in that country. If not, the plaintiff will have to enforce the foreign judgment in the United States, where there is no guarantee that the judgment will be recognized. ${ }^{47}$ To eliminate this concern as a factor in the forum non conveniens determination, a defendant will often agree to pay any judgment rendered by the foreign tribunal as a condition of the dismissal. ${ }^{48}$

As discussed previously, the possibility of an unfavorable change in substantive law is ordinarily given little or no weight in the forum non conveniens inquiry. ${ }^{49}$ However, "if the remedy provided by the alternative forum is so clearly inadequate or unsatisfactory that it is no remedy at all, the unfavorable change in law may be given substantial weight." ${ }^{50}$ In such cases, the Piper Aircraft court observed that the trial court "may conclude that dismissal would not be in the interests of justice." " In other words, the court noted, "where the remedy offered by the other forum is clearly unsatisfactory, the other forum may not be an adequate alternative." ${ }^{, 52}$

This "no remedy at all" component of the "adequate alternative forum" inquiry rarely precludes forum non conveniens dismissals in transnational tort cases. ${ }^{53}$ Courts tend to focus on whether adjudication in the alternative forum is by an independent judiciary applying basic notions of due process, not on whether the plaintiff will be disadvantaged

California law, and pay any final judgment rendered in the Scandinavian courts); Bies, supra note 37, at 501-03 nn.55-69 (collecting cases); Thomas, supra note 37, at 244-62 (collecting cases).

46. Some courts view this consideration as relevant to the balancing of private interest factors. See Gulf Oil Corp. v. Gilbert, 330 U.S. 501, 508 (1947).

47. See infra notes $147-63$ and accompanying text.

48. Many courts have imposed an agreement to pay any judgment on the defendant as a condition of the forum non conveniens dismissal. See authorities cited supra note 45 . But see Bhopal, 809 F. 3d at 204-05 (reversing district court's condition requiring defendant to satisfy any judgment rendered by Indian court based on erroneous assumption that plaintiffs might not otherwise be able to enforce it in the United States).

49. Piper Aircraft Co. v. Reyno, 454 U.S. 235, 247 (1981). The California Supreme Court has ruled that the fact that the alternative forum's law is less favorable should not be accorded any weight in deciding a forum non conveniens motion provided, however, that some remedy is afforded. Stangvik, 819 P.2d at 21 n.9.

50. Piper Aircraft, 454 U.S. at 247.

51. Id. at 254

52. Id. at 255 n.22.

53. See, e.g., Delgado v. Shell Oil Co., 890 F. Supp. 1324, 1357 n.79 (S.D. Tex. 1995); Dunham \& Gladbach, supra note 1, at 675-78 (reviewing cases); Reetz \& Martinez-Fraga, supra note 41 , at 8-10 (reviewing cases). 
by the laws of that jurisdiction. ${ }^{54}$ Only where the alternative forum truly offers no possible remedy, either because it will not recognize the plaintiff's claims or will treat the plaintiff unfairly, does this inquiry provide the basis for denial of a forum non conveniens motion. ${ }^{55}$ In all other circumstances, the alternative forum will be deemed adequate so long as it offers some remedy for the wrongs alleged by the plaintiff. $^{56}$

\section{Why Forum Non Conveniens Motions Are So Important to U.S. Defendants in Transnational Tort Litigation}

The United States is often said to be a "magnet forum" for foreign claimants. $^{57}$ For a variety of reasons, a foreign plaintiff injured abroad prefers to adjudicate a transnational tort case in a U.S. court rather than in the country where the injury occurred. Many of these reasons are procedural, such as trial by jury, liberal pretrial discovery, representation by experienced litigators for a contingent fee, choice of law rules that favor the application of pro-plaintiff domestic law, relatively prompt trial settings, and efficient enforcement of judgments. ${ }^{58}$ Of all these forum

54. E.g., Delgado, 890 F. Supp. at 1357-65; Rasoulzadeh v. Associated Press, 574 F. Supp. 854, 861 (S.D.N.Y. 1983), aff'd, 767 F.2d 908 (2d Cir. 1985).

55. See, e.g., Bhatnagar by Bhatnagar v. Surrendra Overseas Ltd., 52 F.3d 1220, 1227-28 (3d Cir. 1995) (holding extreme delay of fifteen to twenty years in the Indian judicial system rendered the judicial remedy available so "temporally remote that it is no remedy at all"); Martinez v. Dow Chem. Co., 219 F. Supp. 2 d 719 (E.D. La. 2002) (concluding that Costa Rica's, Honduras', and the Philippines' preemptive jurisdiction rules render their forums unavailable); In re Silicone Gel Breast Implants Prod. Liab. Litig., 887 F. Supp. 1469 (N.D. Ala. 1995) (concluding dismissal inappropriate because legislation in the alternative forum precluded plaintiffs from receiving any compensation for implant-related injuries); Laker Airways, Ltd. v. Pan Am. World Airways, 568 F. Supp. 811, 816-17 (D.D.C. 1983) (ruling Britain an inadequate forum to hear plaintiff's federal anti-trust action because Britain does not recognize liability for the defendants' alleged anti-competitive acts).

56. See, e.g., Gonzalez v. Chrysler Corp., 301 F.3d 377 (5th Cir. 2002), cert. denied, 582 U.S. 1012 (2003) (finding Mexican courts adequate even though, due to limitations on damages imposed by Mexican law, plaintiff's wrongful death lawsuit is not economically viable in Mexico and will never be brought there); Lueck v. Sundstrand Corp., 236 F.3d 1137, 1143-45 (9th Cir. 2001) (holding New Zealand accident compensation system provides an adequate remedy despite significant limitations on compensatory damages); PT United Can Co. v. Crown Cork \& Seal Co., 138 F.3d 65, 74 (2d Cir. 1998) ("The availability of an adequate alternate forum does not depend on the existence of the identical cause of action in the other forum."); DiRioennzo, 323 F.3d at 57 (collecting cases); Waples, supra note 35, at 1484 n.50 (collecting cases).

57. See Russell J. Weintraub, Choice of Law for Products Liability: Demagnetizing the United States Forum, 52 ARK. L. REV. 157, 162 (1999) [hereinafter Weintraub, Demagnetizing].

58. See Piper Aircraft Co. v. Reyno, 454 U.S. 235, 252 n.18 (1981); Boyce, supra note 24, at 196-97; Dahl, supra note 5, at 37-42 (examining various reasons why Latin American plaintiffs prefer to litigate in U.S. courts); Figueroa, supra note 5, at 143-50 (same); Manuel A. Gomez, Like Migratory Birds: Latin American Claimants in U.S. Courts and the Ford-Firestone Rollover Litigation, 11 Sw. J. L. \& TRADE AM. 281, 295-97 (2005) (same); Eugene J. Silva, Practical Views on Stemming the Tide of Foreign Plaintiffs and Concluding Mid-Atlantic Settlements, 28 TEX. INT'L L.J. 479, 480-81 (1993); Weintraub, International Litigation, supra note 1, at 323-24. 
shopping reasons, perhaps the most significant is the hope that a U.S. court will apply domestic tort law, which likely will include strict liability instead of negligence, generous measure-of-damages standards that compensate for both economic and non-economic injuries, and the possibility of punitive damages - pro-plaintiff doctrines typically not available in the country where the injury occurred. ${ }^{59}$ Of course, the very same reasons that make litigation in a U.S. court attractive to foreign plaintiffs make such litigation unattractive to domestic defendants.

A motion to dismiss on grounds of forum non conveniens has become the primary response of U.S. defendants to suits by foreign plaintiffs involving transnational torts. This motion is not only filed by the defendant in nearly every such case, but is usually granted. Various elements of the modern doctrine basically guarantee this result where the alleged wrongful act and injury occurred in another country. ${ }^{60}$ As explained previously, the adequate alternative forum prerequisite rarely prevents a court from granting the motion. ${ }^{61}$ A foreign plaintiff's choice of a U.S. forum is accorded little or no deference. ${ }^{62}$ The public interest factors, such as court congestion, local interest in resolving the controversy, and the preference for applying familiar law, favor litigation in the alternative forum, as do the private interest factors, insofar as they are concerned with ease of access to evidence and the convenience of witnesses. ${ }^{63}$

59. See Lueck, 236 F.3d at 1144 (plaintiffs admitted that the motivation for their lawsuit was that U.S. tort law offered greater potential for recovery than New Zealand law and compensation system); Mary Garvey Algero, In Defense of Forum Shopping: A Realistic View at Selecting Venue, 78 NEB. L. REV. 79, 88-93 (1999) (providing examples of cases in which plaintiffs filed claims in the U.S. to take advantage of higher damage awards than were available in foreign jurisdictions); Heiser, supra note 12, at 1177-78 (stating that foreign plaintiffs "hop[e] a court in United States will apply the domestic law of tort liability and damages"); Weintraub, Demagnetizing, supra note 57, at 162 ("[P]laintiffs flock to United States courts because they offer the possibility of higher recoveries and lower barriers to bringing suit.").

60. See Malcolm J. Rogge, Toward Transnational Corporate Accountability in the Global Economy: Challenging the Doctrine of Forum Non Conveniens in In Re: Union Carbide, Alfaro, Sequihua, and Aguinda, 36 TEX. INT'L L.J. 299, 299 (2001) (stating that the doctrine "has proven time and again to be a significant obstacle for [foreign] plaintiffs").

61. See supra notes $30-55$ and accompanying text.

62. See supra notes $26-29$ and accompanying text.

63. See Heiser, supra note 12, at 1175-82 (examining various public interest factors that favor dismissal of foreign plaintiffs' claims); Walter W. Heiser, Toward Reasonable Limitations on the Exercise of General Jurisdiction, 41 SAN DIEGO L. REV. 1035, 1053 n.75 (2004) (collecting cases). 


\section{A Forum Non Conveniens Exemplar: The Delgado Litigation}

Product liability litigation over exposure to toxic pesticides provides a useful example of how the doctrine of forum non conveniens operates to protect U.S. defendants doing business in foreign countries. In the 1990 s, several transnational tort lawsuits were brought in U.S. courts on behalf of thousands of farm workers, citizens of twelve foreign countries, who alleged injuries while working on farms in various foreign countries. ${ }^{64}$ The plaintiffs, mostly banana plantation workers in Central and South America, alleged that they suffered personal injuries, including cancer and chemical castration, as a result of exposure to dibromochloropropane (DBCP), a chemical used in certain pesticides. ${ }^{65}$ The defendants were either U.S. companies that manufactured or exported DBCP, or U.S. companies that owned fruit farms in various countries. ${ }^{66}$ The use of DBCP has been banned in the United States since 1977, but the defendant manufacturers continued to export it, and the defendant farm owners continued to use it outside of the United States. ${ }^{67}$

The suits were eventually consolidated in the United States District Court for the Southern District of Texas under the title Delgado v. Shell Oil Company. ${ }^{68}$ The defendants then filed motions to dismiss all the actions on the grounds of forum non conveniens. ${ }^{69}$ The district court methodically considered whether the courts in the plaintiffs' home countries, such as Costa Rica, Dominica, Ecuador, Guatemala, Honduras, Nicaragua, Panama, and the Philippines, were "available" and "adequate" alternative fora. ${ }^{70}$ The court concluded that each country's court was available and adequate and, after balancing the relevant private and public interest factors, granted the defendants' motions to dismiss. ${ }^{71}$

The Delgado court conditionally granted the forum non conveniens dismissals based upon the defendants' stipulation to waive all

64. Delgado v. Shell Oil Co., 890 F. Supp. 1324, 1335 (S.D. Tex. 1995); Anderson, supra note 10 , at 184 (estimating that nearly 26,000 plaintiffs from developing countries sought compensation from the two primary U.S. defendants, Shell Oil and Dow Chemical).

65. Delgado, 890 F. Supp. at 1335; Anderson, supra note 10, at 189-90 \& n.30; Rogge, supra note 60 , at $303-07$.

66. Delgado, 890 F. Supp. at 1336-40.

67. Anderson, supra note 10, at 189-90 \& n.30; Rogge, supra note 60, at 304.

68. 890 F. Supp. 1324 (1995).

69. Id. at 1351 .

70. Id. at 1355-65. For a general discussion of the Delgado litigation, see Santoyo, supra note 10 , at $720-23$.

71. Delgado, 890 F. Supp. at 1365-75. 
jurisdictional and limitations defenses, and to accept service of process in the alternative forum. ${ }^{72}$ The court also conditioned the dismissals on the defendants' agreements "to satisfy any final judgment rendered in favor of [the] plaintiffs by a foreign court." $"$ Concerned that a foreign tribunal might in fact turn out to be unavailable, the court included a return jurisdiction clause in its dismissal order:

In the event that the highest court of any foreign country finally affirms the dismissal for lack of jurisdiction of any action commenced by a plaintiff in these actions in his home country ... that plaintiff may return to [the district] court and, upon proper motion, the [district] court will resume jurisdiction over the action as if the case had never been dismissed for [forum non conveniens]. ${ }^{74}$

The Delgado dismissals meant that the litigation of thousands of claims must take place, if at all, in the appropriate foreign courts. Numerous individual actions were filed in hundreds of courts in the various affected countries where, predictably, they often encountered procedural obstacles and delay. ${ }^{75}$ Most of these actions were subsequently settled for only a fraction of what the plaintiffs reasonably could have anticipated to recover if the cases had remained in the U.S. court. ${ }^{76}$ Thus, through the vehicle of forum non conveniens, the Delgado defendants converted a handful of potentially ruinous mass tort lawsuits into a series of fragmented actions with relatively minimal individual pay-outs.

\section{RETALIATORY LEGISLATION: LATIN AMERICAN COUNTRIES STRIKE BACK}

As explained above, a forum non conveniens dismissal in a transnational tort action often means a foreign plaintiff will be unable to

72. Id. at $1372-73$.

73. Id. at 1373 .

74. Id. at 1375. After the dismissals, the Costa Rican plaintiffs re-filed their claims in their national courts. Their claims were dismissed for lack of jurisdiction in a case that was affirmed by the Costa Rican Supreme Court. See Delgado v. Shell Oil Co., 322 F. Supp. 2d 798, 801-02 (S.D. Tex. 2004). These plaintiffs then sought to have their claims reinstated in the appropriate U.S. court, pursuant to the return jurisdiction clause. Id. at 810-17.

75. See Anderson, supra note 10, at $184 \mathrm{n} .7$ (indicating that on average each Caribbean claimant recovered less than \$2000); T. Christian Miller, Plantation Workers Look for Justice in the North, L.A. TIMES, May 27, 2007, at A1 (reporting that in a 1997 settlement Dow Chemical and other companies paid $\$ 41.5$ million to 26,000 workers worldwide).

76. Anderson, supra note 10, at 184. 
adequately redress his injuries. ${ }^{77}$ The likelihood of this consequence has frustrated not only foreign plaintiffs whose cases were dismissed, but also their home countries. As a reaction to the Delgado dismissals in particular, some countries in Latin America enacted statutes specifically designed to counter forum non conveniens dismissals of transnational tort actions brought by their residents against U.S. defendants in U.S. courts. $^{78}$

This retaliatory legislation has taken two forms. Some countries have adopted limits on jurisdiction that apparently preclude courts from hearing any action by one of their residents that was previously commenced in another country and later dismissed based on forum non conveniens. ${ }^{79}$ Although such legislation often refers generically to cases where the plaintiff resorts to his country's national courts because of dismissal by foreign judges when the foreign judges had jurisdiction, there is little doubt that this type of blocking statute is intended specifically to prevent courts in the United States from finding that an alternative forum is "available" to hear the plaintiff's lawsuit. ${ }^{80}$ Other countries have adopted choice-of-law statutes that, at a minimum, authorize their courts to apply tort liability and damages law similar to that of the country in which the action was originally filed. ${ }^{81}$ The intent behind these statutes is to make tort litigation in the courts of these countries no more attractive to U.S. defendants than tort litigation in courts located in the United States. ${ }^{82}$ Both types of retaliatory legislation are discussed in more detail below.

77. See supra notes $4-6$ and accompanying text.

78. See Anderson, supra note 10, at 187-213 (discussing Dominica's statutes); Dahl, supra note 5, at 47-63 (setting forth statutory provisions from Ecuador, Guatemala, Dominica, Nicaragua, Costa Rica, and the Philippines); Figueroa, supra note 5, at 156-59 (surveying legislation enacted by several Latin American countries); Zanifa McDowell, Forum Non Conveniens: The Caribbean and Its Response to Xenophobia in American Courts, 49 INT'L \& COMP. L.Q. 108, 115-28 (2000) (discussing Dominica's statutes); Santoyo, supra note 10, at 729-32 (discussing Nicaragua's legislative response).

79. See infra notes $83-88$ and accompanying text.

80. See Dahl, supra note 5, at 21 (stating that "some countries in [Latin America] have enacted special statutes to block [forum non conveniens]"); Figueroa, supra note 5, at 156-61 (asserting that new statutes in Latin American countries were enacted in response to dismissals in the U.S. based on forum non conveniens).

81. These countries include Nicaragua and the Commonwealth of Dominica. See Anderson, supra note 10, at 187 (analyzing the Dominica legislation); Dahl, supra note 5, at 50-53 (reproducing an English translation of the Nicaraguan statutes).

82. See Anderson, supra note 10, at 185-215 (discussing so-called "anti-forum non conveniens" statutes); Figueroa, supra note 5, at 156-59 (examining new statutes in Latin American countries); Santoyo, supra note 10, at 727 (stating that Latin American countries were "trying to make their forums less attractive"). 


\section{A. Blocking Statutes Preclude Subject Matter Jurisdiction}

Several countries in Latin America, including Costa Rica, Honduras, Guatemala, and Venezuela, have enacted legislation that extinguishes the jurisdiction of their courts with respect to any tort claim first filed against a foreign defendant in a foreign court but later dismissed on grounds of forum non conveniens. ${ }^{83}$ The precise effect of these blocking statutes is unclear however, because they typically indicate that jurisdiction may be restored if the resident plaintiff dismisses his foreign lawsuit and files a new action in the national courts "in a completely free and spontaneous way." alternative forum is not available when the plaintiff was forced out of a U.S. court due to a forum non conveniens dismissal. ${ }^{85}$ Other courts have interpreted that language to mean the alternative forum is available, despite the plaintiff's unwillingness to commence suit in that forum. ${ }^{86}$

This Article assumes that countries have enacted, or will enact, statutes that render their courts jurisdictionally incompetent to hear cases that were previously dismissed from a U.S. court based on forum non conveniens. So far, only a few countries actually have such blocking statutes. ${ }^{87}$ However, if these statutes successfully prevent forum non conveniens dismissals, other countries will undoubtedly follow suit. ${ }^{88}$

83. See Martinez v. Dow Chem. Co., 219 F. Supp. 2d 719, 725-28, 735-37 (E.D. La. 2002) (examining the preemptive jurisdiction statutes of Costa Rica and Honduras); In re Bridgestone/Firestone Inc., 190 F. Supp. 2d 1125, 1125-32 (S.D. Ind. 2002) (finding Venezuelan courts unavailable due to a preemptive jurisdiction statute). But see Morales v. Ford Motor Co., 313 F. Supp. 2d 672, 689 (S.D. Tex. 2004) (concluding Venezuela is an available alternative forum); Dahl, supra note 5, at 22-24, 47-63 (analyzing various Latin American preemptive jurisdiction statutes); Figueroa, supra note 5, at 150-59 (discussing jurisdictional rules in Latin America). One court has also concluded the Philippines' jurisdictional limitations statutes rendered its courts unavailable for purposes of forum non conveniens. Martinez, 219 F. Supp. 2d at 738-40.

84. Michael Wallace Gordon, Forum Non Conveniens Misconstrued: A Response to Henry Saint Dahl, 38 U. MiAmi INTER-AM. L. Rev. 141, 177 (quoting DAHL, DAHL's LAW DictionaRY at 240). See also authorities cited supra note 82.

85. See, e.g., Martinez, 219 F. Supp. 2d at 741 (concluding that courts in Costa Rica, Honduras, and the Philippines were not available as alternative forums); In re Bridgestone/Firestone, Inc., 190 F. Supp. 2d at 1129 (finding courts in Venezuela are unavailable).

86. E.g., Leon v. Million Air, Inc., 251 F.3d 1305, 1315 (11th Cir. 2001) (finding Ecuadorian courts available and adequate); Morales, 313 F. Supp. 2d at 689 (finding courts in Venezuela available); Chandler v. Multidata Sys. Int'l Corp., 163 S.W.3d 537, 551 (Mo. Ct. App. 2005) (concluding that courts in Panama are available to plaintiffs).

87. See supra notes 83-86 and accompanying text.

88. In 1998, PARLATINO, an acronym for Latin American Parliament, an international organization formed by representatives of Latin American countries whose pronouncements are not binding on these countries but have persuasive authority, approved a model law to counter forum non conveniens dismissals and recommended that all member countries adopt similar legislation. See Dahl, supra note 5, at 22-24 \& 47; Gordon, supra note 84, at 176-79; Santoyo, supra note 10, at 724-25. This model law provides in part: 
These blocking statutes may have a profound effect on forum non conveniens motions filed in U.S. courts, as discussed below.

\section{B. Blocking Statutes and Determining Whether the Alternative Forum is "Available" and "Adequate"}

Under the traditional common law doctrine set forth in Gilbert and Piper and followed in federal ${ }^{89}$ and most state courts, a court must first ascertain whether an adequate alternative forum is available when determining whether a forum non conveniens dismissal is appropriate. ${ }^{90}$ If the law in the alternative country prohibits jurisdiction over the plaintiff's claim when the plaintiff first files in another country with competent jurisdiction, then the alternative forum is simply not available to the plaintiff. ${ }^{91}$ So far, a handful of courts have followed this line of reasoning and denied motions to dismiss for forum non conveniens. ${ }^{92}$

As expected, defendants have argued strenuously against this result, even when the court has already concluded that the plaintiffs' claims cannot be heard in the alternative forum. According to defendants, there are good reasons why U.S. courts should not permit the doctrine of forum non conveniens to be countered in this manner. However, none of these arguments are particularly persuasive, at least in the context of current doctrine.

One argument is that denying a motion to dismiss based on another country's blocking statute permits foreign law to trump the doctrine of

Art. 1. National and international jurisdiction. The petition that is validly filed, according to both legal systems, in the defendant's domiciliary court, extinguishes national jurisdiction. The latter is only reborn if the plaintiff desists of his foreign petition and files a new petition in the country, in a completely free and spontaneous way. Dahl, supra note 5 , at 47.

89. Although this Erie doctrine question is not entirely settled, most federal courts apply the federal common law version of forum non conveniens as set forth in Gilbert and Piper. E.g., De Aguilar v. Boeing Co., 11 F.3d 55, 58 (5th Cir. 1993); Royal Bed \& Spring Co. v. Famossul Industria e Comercio de Moveis, Ltda., 906 F.2d 45, 50 (1st Cir. 1990); Sibaja v. Dow Chem. Co., 757 F.2d 1215, 1219 (11th Cir. 1985), cert. denied, 474 U.S. 948 (1985).

90. See supra notes 30-56 and accompanying text.

91. See Alejandro M. Garro, Forum Non Conveniens: "Availability" and "Adequacy" of Latin American Fora from a Comparative Perspective, 35 U. MiAMI INTER-AM. L. REV. 65 (2004) (discussing civil law rules in Latin American countries that compel their courts to respect the plaintiff's right to sue at the place where the defendant is domiciled); Figueroa, supra note 5, at 15059 (discussing Latin American rules on jurisdiction).

92. E.g., In re Bridgstone/Firestone, Inc., 190 F. Supp. 2d 1125, 1129-32 (S.D. Ind. 2002), mandamus denied, 344 F.3d 648 (7th Cir. 2003); Martinez v. Dow Chem. Co., 219 F. Supp. 2d 719, 741 (E.D. La. 2002). Cf. In re Bridgestone/Firestone, Inc., 420 F.3d 702 (7th Cir. 2005) (ruling Mexico is not an alternative forum if Mexican courts lack jurisdiction over defendants, despite defendant's consent to suit there). 
forum non conveniens. ${ }^{93}$ The implication here is that a foreign country "should not be able to dictate" what cases a U.S. court must hear. ${ }^{94}$ Viewed from a U.S. perspective, this appears to be a reasonable argument. After all, each sovereign does have the power to determine what cases its courts will and will not hear. However, this inherent power to limit jurisdiction applies to each sovereign whose courts might be asked to adjudicate a particular transnational dispute, not just to the United States.

The United States has chosen to limit the jurisdiction of its courts based on the common law doctrine of forum non conveniens. This doctrine functions as a blocking statute, albeit a discretionary one, which permits a court to decline to hear a particular case brought by a foreign plaintiff even though the case is clearly within the court's jurisdiction. ${ }^{95}$ Other countries, such as Costa Rica, have chosen to limit the jurisdiction of their courts based on preemptive jurisdiction statutes that are consistent with their civil law traditions. ${ }^{96}$ Viewed from a multilateral perspective, the United States and each of these other countries have simply exercised their respective sovereign powers to control the jurisdiction of their own courts. ${ }^{97}$

A foreign country's preemptive jurisdiction statute does not compel a U.S. court to hear a transnational tort action any more than a forum non conveniens dismissal compels a foreign plaintiff to commence a lawsuit in the alternative forum. ${ }^{98}$ After a dismissal, a foreign plaintiff may decide to commence a lawsuit in her home country or may decide, as is often the case, not to sue at all. ${ }^{99}$ Likewise, a court in the United States may decide - and probably should under the current doctrine - to deny a forum non conveniens motion and retain jurisdiction due to the existence

93. This argument was made by the defendants in Martinez. 219 F. Supp. 2d at 730-31.

94. Martinez, 219 F. Supp. 2d at 731; Bernard H. Oxman, Comments on Forum Non Conveniens Issues in International Cases, 35 U. MIAMI INTER-AM. L. REV. 123, 128 (2004).

95. Even though forum non conveniens is often characterized as not jurisdictional, this doctrine is part of the law governing access to U.S. courts. Oxman, supra note 94, at 126. Cf. Sinochem Int'1 Co. v. Malaysia Int'l Shipping Corp., 127 S. Ct. 1184 (2007) (holding district court may grant forum non conveniens dismissal without first resolving whether it has subject matter or personal jurisdiction).

96. See Garro, supra note 91, at 72-76 (discussing civil law jurisdictional rules in Latin America in general and in Costa Rica in particular). Also, the doctrine of forum non conveniens is alien to civil law countries, as is any doctrine that would authorize courts, as a matter of discretion, to deny jurisdiction. Id. at 74-78. See also Heiser, supra note 12, at 1187 ("[T] he overwhelming majority of other countries do not recognize the doctrine of forum non conveniens.").

97. See Gordon, supra note 84, at 159 ("If the defendant, or its nation wants to make that nation unavailable selectively that is the prerogative of that foreign nation's sovereignty.").

98. Oxman, supra note 94, at 123-24; Gordon, supra note 84, at 151-55, 159.

99. See supra note 4 and accompanying text. 
of a blocking statute but is not compelled to do so by the foreign country's statute. A U.S. court's decision is purely a matter of the domestic law of forum non conveniens. Although under the current doctrine a court in the United States should deny a motion to dismiss because no alternative forum in available, each jurisdiction is free to adopt new limitations in its court access doctrines, including forum non conveniens. ${ }^{100}$

Some have argued that the motive behind another country's retaliatory legislation should be considered in determining whether that country's courts are available. ${ }^{101}$ In the case of Ecuador, for example, the preemptive jurisdiction statute is clearly intended to prevent forum non conveniens dismissals of actions brought by Ecuadorian plaintiffs in U.S. courts. ${ }^{102}$ Why this motive is relevant is difficult to understand. ${ }^{103}$ The relevant inquiry under the current forum non conveniens analysis is whether an alternative forum is in fact available, not why the alternative forum is unavailable. ${ }^{104}$

Perhaps, as some defendants have argued, it is simply "unfair" for another country to enact legislation that undercuts forum non conveniens and thereby causes a court in the United States to hear all cases within its jurisdiction. ${ }^{105}$ One response to this argument is that these blocking statues are no more unfair to domestic defendants than the doctrine of forum non conveniens is to foreign plaintiffs. In one sense, either can be viewed as fair or unfair, depending on the perspective. For example, in the academic debate, those who favor forum non conveniens argue the

100. See Gordon, supra note 84 , at $155-56,183$ (suggesting that U.S. courts may alter the availability requirement of forum non conveniens); Oxman, supra note 94 (justifying modification of forum non conveniens to permit dismissal when the alternative forum is unavailable due to a blocking statute).

101. See Gordon, supra note 84 , at $155-56,183-84$.

102. See Garro, supra note 91, at 78-79.

103. In other procedural areas, such as discovery of information located abroad pursuant to Rule 34 of the Federal Rules of Civil Procedure, foreign countries have enacted blocking statutes specifically designed to thwart U.S. court orders for production of documents. See Societe Nationale Industrielle Aerospatiale v. U.S. Dist. Court, 482 U.S. 522, 526 n.6 (1987) (French blocking statute prevents disclosure of documents); Societe Internationale v. Rogers, 357 U.S. 197, 200 (1958) (explaining that disclosure of records would violate Swiss penal laws). When determining the appropriate consideration, if any, these discovery-blocking statutes deserve, courts typically give little or no adverse weight to the foreign county's motive in enacting them, but do balance the sovereign interests of that country and the United States and do consider whether the responding party has made a good faith effort to seek a wavier. Rogers, 357 U.S. at 204-06; Richmark Corp. v. Timber Falling Consultants, 959 F.2d 1468, 1474-79 (9th Cir. 1992); Reinsurance Co. of Am., Inc. v. Administratia Asigurarilor de Stat, 902 F.2d 1275, 1279-83 (7th Cir. 1990). Restatement (THIRD) FOREIGN RELATIONS LAW § 442 (1987).

104. Norex Petroleum, Ltd. v. Access Indus., 416 F.3d 146, 159 (2d Cir. 2005).

105. Martinez v. Dow Chem. Co., 219 F. Supp. 2d 719, 731 (E.D. La. 2002). 
doctrine is "fair" to U.S. defendants because it protects those defendants doing business overseas from ruinous damage awards, and thereby ensures that foreign plaintiffs are not "overcompensated" merely because they were injured by U.S., as opposed to foreign, tortfeasors. ${ }^{106}$ Those who oppose the doctrine argue that it is fundamentally "unfair" to foreign plaintiffs because they will recover little or nothing in their national courts, thereby permitting U.S. companies, who take advantage of their dominant role in the global economy, to avoid moral and ethical accountability for injuries caused overseas. ${ }^{107}$

A more appropriate response to this notion of fairness to the defendant is that it is simply not relevant in the context of a forum non conveniens motion. ${ }^{108}$ Fairness to the defendant $i s$ the relevant concern when a U.S. court determines whether to exercise personal jurisdiction over the defendant. Indeed, fairness to the defendant is the central due process inquiry under the "minimum contacts" analysis, and plays an important role in the determination of whether the exercise of personal jurisdiction in a specific case is reasonable. ${ }^{109}$ Certainly there is no unfairness to a defendant who must litigate in its place of residence. Any "unfairness" due to a blocking statute is more likely to be felt by the U.S. court that now must litigate an action that otherwise would be dismissed

106. See Dorward, supra note 1, at 151-57 (arguing forum shopping leads to arbitrary and inefficient remedies in international litigation); Reynolds, supra note 1, at 1708 (arguing that if an American court were to award damages several times higher than an Indian court would, Indian social policy would be disrupted); Weintraub, International Litigation, supra note 1, at 336 (arguing that for most products liability actions it makes no sense to provide a foreign plaintiff with more recovery than she would get under her own law).

107. See Jacqueline Duval-Major, Note, One-Way Ticket Home: The Federal Doctrine of Forum Non Conveniens and the International Plaintiff, 77 CORNELL L. REV. 650, 672-75 (1992) (explaining the diminished results by plaintiffs in foreign jurisdictions and how defendants evade responsibility for their actions); Alan Reed, To Be or Not to Be: The Forum Non Conveniens Performance Acted Out on Anglo-American Courtroom Stage, 29 GA. J. INT'L \& COMP. L. 31, 60 (2000) (explaining that U.S. courts are "condoning corporate malpractice, negligence, and harmful conduct" by dismissing such cases); David W. Robertson, The Federal Doctrine of Forum Non Conveniens: "An Object Lesson in Uncontrolled Discretion,” 29 TEX. INT'L L.J. 353, 364 (1994) (explaining how plaintiffs whose claims are dismissed as forum non conveniens are unable to continue in foreign forums); Rogge, supra note 60, at 300-01 (explaining how forum non conveniens leaves foreign plaintiffs without a legal remedy and insulates corporations from liability).

108. Cf. Martinez, 219 F. Supp. 2d at 731 (noting that the court would not even consider a forum non conveniens motion if it had not first established that it is fundamentally fair for the action to proceed against the defendants in this court).

109. See Asahi Metal Indus. Co. v. Superior Court, 480 U.S. 102, 114 (1987) (identifying the "burden on the defendant" as a significant factor in determining whether the exercise of personal jurisdiction is reasonable); Int'1 Shoe Co. v. Washington, 326 U.S. 310, 316 (1945) (ruling due process requires that a defendant have minimum contacts with the forum state such that maintenance of the suit does not offend "traditional notions of fair play and substantial justice"). 
from its docket. Of course, a court can remedy this unfairness by making appropriate changes to the doctrine of forum non conveniens. ${ }^{110}$

\section{Retaliatory Legislation Imports United States Tort Law into Foreign Tribunals}

Two countries, Nicaragua and the Commonwealth of Dominica, have enacted legislation designed to afford resident plaintiffs many of the same substantive law benefits they would have enjoyed in a U.S. court if their lawsuits were not dismissed based on forum non conveniens. The specific statutory provisions of the Dominican statutes differ somewhat from Nicaragua's, but they share a common retaliatory approach. Unlike the jurisdiction-blocking statutes discussed above, these statutes invite a resident plaintiff to sue in the courts of his country after a forum non conveniens dismissal from a U.S. court.

\section{Dominica's Transnational Cause of Action (Product Liability) Act}

Dominica's legislation, entitled the Transnational Cause of Action (Product Liability) Act of 1997, applies to all transnational causes of action brought against a foreign defendant where "such action was dismissed in a foreign forum on the basis of forum non conveniens."111 The Transnational Act provides for jurisdiction in the courts of Dominica in all cases in which the Act applies, and prohibits dismissal of such cases based on Dominica's domestic doctrine of forum non conveniens. ${ }^{112}$ Where there are multiple plaintiffs, the Transnational Act authorizes consolidation of actions, a representative action or a class action. ${ }^{113}$ If a foreign defendant enters an appearance, the Act authorizes the court to order the defendant to deposit "a bond in the amount of one

110. One approach would be to treat the availability of an alternative forum as an important factor, but not as an absolute prerequisite to dismissal. See infra notes 273-76 and accompanying text.

111. Transnational Causes of Action (Products Liability) Act, No. 16, $§ 3$ (1997) (Dominica) [hereinafter Transnational Act]. See Anderson, supra note 10, at 187-88 (discussing the purpose of the Act). Dominica's adoption of the Transnational Act likely was a response to the forum non conveniens dismissal in Delgado v. Shell Oil Co., which is discussed supra notes 64-76 and accompanying text. See Anderson, supra note 10, at 184-87 (explaining that Delgado prompted Dominica to enact retaliatory legislation); McDowell, supra note 78, at 115-16.

112. Transnational Act, $\S 4$; see Anderson, supra note 10, at 195-99. Dominica is one of the few countries that recognizes the doctrine of forum non conveniens domestically, which may in part explain why Dominica did not enact a blocking statute. Dahl, supra note 5, at 24 .

113. Transnational Act, $\S 6$. These provisions seek to counter the fragmentation of individual local actions that might occur after a forum non conveniens dismissal. See Anderson, supra note 10, at $199-202$. 
hundred and forty percent per claimant of the amount proved by the plaintiff to have been awarded in similar foreign proceedings." ${ }^{114}$ The purpose of this provision is to permit a successful plaintiff to satisfy a judgment "from the bond itself." 115 The terms and conditions for the posting and disposal of this bond "shall be determined by the court."116

The Act also contains a choice of law provision. In a tort action, "the rights and liabilities of the parties with respect to a particular issue or the whole cause of action shall be determined by the local law of the country" that has "the most significant relationship to the cause of action and the parties." 117 In making this determination, the court must "take into account all relevant circumstances," including such factors as: (a) "the place where the injury occurred; (b) the domicile ... and place of business of the parties; and (c) the place where the relationship... between the parties is centered." 118 The adoption of this "most significant relationship" test makes it possible for a court in Dominica to apply the tort law of another country, or of a state of the United States. ${ }^{119}$ However, where a transnational tort to which the Act applies is governed by the law of Dominica, the Act imposes strict liability upon any person "who manufactures, produces, distributes or otherwise puts any product or substance into the stream of commerce" which results in harm or loss. ${ }^{120}$

Other features of the Transnational Act address the inefficiencies that attend litigation after a forum non conveniens dismissal. One section states that Dominican courts "shall take judicial notice of evidence presented and accepted by foreign courts in similar proceedings involving the same or similar parties, or the same or similar causes of

114. Transnational Act, § 5. See Anderson, supra note 10, at 203-05; McDowell, supra note 78, at $121-22$.

115. Anderson, supra note 10 , at 203-04. The amount of the bond- $140 \%$ of the total claimcovers an award of damages as well as litigation costs. Id. A secondary purpose of this bond requirement may be to "make trial in Dominica unattractive" to foreign defendants, "thereby promot[ing] trial in the defendant's home court[s]." Id. at 205.

116. Transnational Act, $\S 5(2)$. "[T] $]$ he plaintiff bears the burden of proving (a) the similarity of foreign proceedings, and (b) the amount awarded in those proceedings." Anderson, supra note 10, at 204. "The court may [also] require[ ]the plaintiff [to] prove that there is a substantial issue to be tried and that [the plaintiff has a] reasonable likelihood of success." Id. "[A] defendant who is unhappy with the court's [bond] decision has [the] right [to] appeal. Id.

117. Transnational Act, § 7. See Anderson, supra note 10, at 205.

118. Transnational Act, $\$ 7$. Anderson, supra note 10, at 205-06.

119. See Anderson, supra note 10, at 206-07 (stating that "Dominica's law ... determines the identity of, but need not itself be, the governing law").

120. Transnational Act, $\S 8$. McDowell, supra note 78, at 124-25; Anderson, supra note 10, at 208 
action."121 This provision permits a Dominican court simply to adopt the findings of fact entered by a court in the United States rather than to receive evidence, such as expert witness testimony, and decide issues anew. ${ }^{122}$

Perhaps the most important aspect of the Transnational Act is its provisions regarding damages. The Act is somewhat unclear as to whether an award of compensatory damages is calculated based on the common law rules of Dominica or is subject to the "most significant relationship" choice of law provision. ${ }^{123}$ However, more significantly, the Act authorizes a Dominican court to award punitive or exemplary damages in certain limited circumstances. ${ }^{124}$ Punitive damages may be awarded only where the court finds that "the defendant acted in bad faith or in reckless disregard for the welfare of others; or having knowledge of the harm ... nevertheless persist[s] in the relevant action with a view to making a profit." ${ }^{\prime 25}$ The Act then specifies several factors the court must take into account when deciding whether an award of punitive damages is appropriate. ${ }^{126}$ The plaintiff bears the burden of proof with respect to establishing these various factors. ${ }^{127}$

Dominica's recognition of punitive damages is, in itself, groundbreaking. ${ }^{128}$ But the Transnational Act goes further. When awarding punitive damages, the court "shall consider and be guided by awards made in similar proceedings ... in other jurisdictions, in particular damages awarded in the Courts of the country with which the defendant has a strong connection whether through residence, domicile,

121. Transnational Act, § 9. See McDowell, supra note 78, at 125.

122. See Anderson, supra note 10, at 208-09 (stating that "[w]ithout this evidence the court in the plaintiff's home country would have to start from scratch").

123. Transnational Act, § 10. Compare Anderson, supra note 10, at 212-13 (interpreting the Act to mean that domestic Dominican law, not foreign law, applies when determining the amount of compensatory damages), with McDowell, supra note 78, at 127-28 (suggesting the Act may authorize a Domincan court to apply the tort damages law of another country).

124. Transnational Act, § 11. Anderson, supra note 10, at 210-13; McDowell, supra note 78, at $126-28$.

125. Transnational Act, § 11(1). Dahl, supra note 5, at 49-50.

126. The relevant factors are whether: (a) the defendant continued to produce or sell any product ... after the product ... was banned or its use restricted in the country of manufacture or in any other country in which it was used or consumed; (b) the defendant failed to warn the Government of Dominica or to any other relevant person of the harmful effects of the product; (c) a warning that was issued was inadequate; and (d) the defendant had been guilty of relevant culpable past conduct. See Transnational Act, § 11(2).

127. See Anderson, supra note 10, at 212 (stating that "the plaintiff bears a heavy burden").

128. Outside the United States, very few jurisdictions endorse the concept of punitive damages in civil litigation between private parties. See generally Linda L. Schlueter, PuniTIVE DAMAgES $\S$ $22.1 \& \S 22.2$ (LexisNexis 2005) (reviewing punitive damages laws in other countries). 
[or] the transaction of business." 129 In other words, when the defendant is from the United States, the Act requires a Dominican court to calculate a punitive damages award based on the amounts awarded by U.S. courts in similar cases. ${ }^{130}$ When making this comparison, the court must "take judicial notice of awards made in relevant foreign [proceedings]."131

\section{Nicaragua's Special Law No. 364}

In 2001, the National Assembly of Nicaragua passed the "Special Law for the Conduct of Lawsuits Filed by Persons Affected by the Use of Pesticides Manufactured with a DBCP Base," known as "Special Law No. 364." "132 Unlike Dominica's legislation, the scope of Special Law No. 364 is limited to lawsuits for damages filed by persons whose "health has been adversely affected by the use and application of the DBCP pesticide." 133 Like Dominica's legislation, Special Law 364 authorizes a civil cause of action against enterprises that manufacture, distribute, or apply DBCP products, and who were sued in the United States but opted to have the lawsuits "transferred" to Nicaraguan courts based on forum non conveniens. ${ }^{134}$ Such an enterprise will be liable in the minimum amount of $\$ 100,000$ to each plaintiff who can show that "his health has been physically or psychologically affected" by the defendant enterprise's DBCP product. ${ }^{135}$ A defendant enterprise must post a bond in the amount of $\$ 100,000$ per claimant within ninety days of the filing of the lawsuit to cover the costs of litigation and any future judgment as a procedural condition for participation in the lawsuit. ${ }^{136}$

Special Law No. 364 also appears to authorize the same type of civil action to be filed initially by Nicaraguan plaintiffs in Nicaraguan courts. ${ }^{137}$ However, regardless of whether the action was first commenced in Nicaragua or the United States, a defendant has the option

\footnotetext{
129. Transnational Act, § 12(1). See Dahl, supra note 5, at 49-50.

130. See Anderson, supra note 10, at 210-13 (stating that the court looks to "awards made in similar proceedings in other jurisdictions").

131. Transnational Act, $\S 12(2)$. Dahl, supra note 5, at 50 .

132. La. Gac. 12, 17 de Enero de 2001 (Nicar. 2001). See Henry Saint Dahl's article for an English translation of the text of Special Law No. 364. Dahl, supra note 5, at 50-53.

133. Special Law No. 364, art. 1.

134. Special Law No. 364, art. 3. Civil liability attaches to "enterprises who import, distribute, market [or] apply such products in Nicaragua" and who had "knowledge of the [adverse] effects caused by [these] pesticides on humans." Id. art. 2.

135. Id. art. 3 .

136. Id. arts. 4-5.

137. See Santoyo, supra note 10, at 729-34 (stating that "Nicaragua required a set bond amount of $\$ 100,000$ per claimant”).
} 
not to post the required bond but instead to agree to litigate in a U.S. court, expressly waiving use of forum non conveniens in that court. ${ }^{138}$ If the defendant opts to remain in the Nicaraguan court, it must not only deposit the $\$ 100,000$ bond per claimant but must also post the additional amount of three hundred million Nicaraguan Cordobas (approximately $\$ 17.5$ million) to guarantee payment of any eventual judgment. ${ }^{139}$ Special Law No. 364 contains no specific authority for a defendant to contest the imposition of the costs and judgment bonds. ${ }^{140}$

Special Law No. 364 establishes civil liability, and makes proof of causation very easy when the plaintiff alleges that he was rendered sterile as a consequence of exposure to the pesticide. Proof that the plaintiff has been exposed to DBCP pesticide and has been rendered sterile gives rise to an irrebuttable presumption that his sterility was caused by the pesticide. ${ }^{141}$ With respect to damages, Special Law No. 364 establishes minimum amounts payable for certain injuries, authorizes "moral" damages, and apparently permits consideration of foreign law when determining the relevant amount of damages. ${ }^{142}$

Of course, a defendant can simply decline to appear in a Nicaraguan court. If that court determines it possesses jurisdiction over the defendant, the consequence of nonappearance will be a default judgment. However, that judgment may be worthless unless the defendant has reachable assets in Nicaragua. Relying on Special Law No. 364, over 400 banana workers commenced actions in Nicaragua against several U.S. companies, including Shell Oil, Dole Food, and Dow Chemical seeking damages for injuries allegedly caused by exposure to DBCP, including sterility, cancer, and birth defects in their children. ${ }^{143}$ After a trial in which the defendants refused to take part, the Nicaraguan court entered a default judgment for the plaintiffs in the amount of $\$ 489.4$ million. ${ }^{144}$ The defendants refused to pay and have successfully defeated the plaintiffs' efforts to enforce this judgment in U.S. courts on the

\footnotetext{
138. See Special Law No. 364, art. 7 (stating that the party "shall submit unconditionally to the jurisdiction of the courts of the United States... expressly waiving the exception of forum non conveniens").

139. Id. art. 8 .

140. See id. arts. 7-9 (lacking an express avenue to contest costs or judgment bonds).

141. Id. art. 9.

142. Id. arts. $10-12$.

143. David Gonzalez \& Samuel Loewenberg, Banana Workers Get Day in Court, N.Y. TIMES, Jan. 18, 2003, at C1.

144. Id.
} 
grounds of improper service of process and lack of personal jurisdiction by the Nicaraguan court. ${ }^{145}$

3. A Preliminary Look at the Impact Retaliatory Legislation Has on Forum Shopping in Transnational Tort Litigation

Nicaragua's Special Law No. 364 contains interesting forum shopping aspects. The provisions that offer defendants a choice of forum to avoid the onerous deposits appear to be designed to encourage defendants to litigate in U.S., rather than Nicaraguan, courts. On the other hand, the provisions that remove financial barriers to suit by plaintiffs in Nicaragua by authorizing free legal assistance and waiver of costs, as well as the provisions dealing with causation and damages, appear designed to encourage Nicaraguan plaintiffs to commence their lawsuits in the Nicaraguan courts. ${ }^{146}$ Special Law No. 364 may therefore discourage defendants from seeking forum non conveniens dismissals because of the high likelihood that the plaintiffs will re-file in Nicaragua and obtain a substantial money judgment. At least with respect to defendants facing DBCP exposure claims, litigation in Nicaragua may no longer be preferable to litigation in the United States.

Likewise, Dominica's Transnational Act may make litigation in a Dominican court less attractive to a U.S. defendant than litigation in a U.S. court. The possibility of a judgment of punitive damages, determined by a Dominican court but calculated based on U.S. awards, may deter a defendant from seeking a forum non conveniens dismissal, particularly when combined with the requirement that the defendant must post a pre-appearance bond in an amount necessary to satisfy that judgment. Moreover, along with the possibility of a large damages judgment satisfied from a bond, the liberalized joinder and evidentiary provisions of the Act mean that a plaintiff is far more likely to re-file in a Dominican court after a forum non conveniens dismissal.

However, two overriding inquiries determine whether legislation such as Dominica's and Nicaragua's will have any significant effect on a defendant's use of forum non conveniens in a U.S. court. One is whether the defendant's assets in the country that renders a judgment are

145. Franco v. Dow Chem. Co., No. CV 03-5094 NM, 2003 WL 24288299, at *8 (C.D. Cal. Oct. 20, 2003). See Dow Chem. Co. v. Calderon, 422 F.3d 827 (9th Cir. 2005) (dismissing declaratory judgment action brought by U.S. companies against Nicaraguan individuals); Dole Food Co. v. Gutierrez, No. CV 03-9416 NM (PJWX), 2004 WL 3737123, at*15 (C.D. Cal. July 13, 2004).

146. Special Law No. 364, arts. 4 \& 13 . 
sufficient to satisfy the judgment. If, as is frequently the case, the defendant does not have sufficient assets reachable in the rendering country but does in the United States, the second inquiry is whether the judgment will be recognized and enforced by a U.S. court. The significance of the answers to these inquiries, as well as their impact on forum non conveniens, is the subject of the next section of this Article.

\section{ENFORCEMENT OF FOREIGN JUDGMENTS RENDERED PURSUANT TO RETALIATORY LEGISLATION}

\section{A. Enforcement of Foreign Judgments}

As often noted, there is no international Full Faith and Credit Clause. ${ }^{147}$ Consequently, each country is free to adopt whatever standards for recognition and enforcement of foreign judgments it deems appropriate. Beginning in the late 19th century, jurisdictions in the United States generally recognized foreign judgments on grounds of comity. ${ }^{148}$ Prior to the decision in Erie Railroad Company $v$. Thompkins, ${ }^{149}$ the standards for recognition by federal courts were based on federal common law. ${ }^{150}$ After Erie, unless a treaty or federal statute applies, the relevant standards are matters for state law. ${ }^{151}$ Because no comprehensive treaty or federal statute currently exists, recognition and enforcement of foreign judgments is now governed by state law, with the concomitant potential of fifty different standards. ${ }^{152}$

Fortunately, a majority of states have enacted a highly influential model law, the Uniform Foreign Money-Judgments Recognition Act (UFMJRA). ${ }^{153}$ Many of the remaining states have adopted the standards of the UFMJRA, or the substantially similar Restatement (Third) of

147. See, e.g., Ronald A. Brand, Enforcement of Foreign Money-Judgments in the United States: In Search of Uniformity and International Acceptance, 67 NOTRE DAME L. REV. 253, 258-65 (1991); Linda J. Silberman, The Impact of Jurisdictional Rules and Recognition Practice on International Business Transactions: The U.S. Regime, 26 Hous. J. INT'L L. 327, 352 (2004) [hereinafter Silberman, Impact]; Katherine R. Miller, Playground Politics: Assessing the Wisdom of Writing a Reciprocity Requirement into U.S. International Recognition and Enforcement Law, 35 GEO. J. INT'L L. 239, 243-44 (2004).

148. Hilton v. Guyot, 159 U.S. 113, 163-64 (1895); Brand, supra note 147, at 258-62.

149. 304 U.S. 64 (1938).

150. Hilton, 159 U.S. at 164

151. See Brand, supra note 147, at 262-63; Miller, supra note 147, at 251 .

152. See Brand, supra note 147, at 262-63; Miller, supra note 147, at 251

153. See Unif. Foreign Money-Judgments ReCOGnition Act, 13 U.L.A. (Part II) 39 (2002 and Supp. 2007). 
Foreign Relations Law, as their common law doctrine. ${ }^{154}$ As a result, even though state law governs, the grounds for recognition and enforcement of foreign judgments are nearly the same in any court in the United States. ${ }^{155}$ Therefore, for purposes of analysis, this Article will treat the provisions of the UFMJRA as setting forth the relevant standards with respect to whether a court in the United States will enforce a foreign money judgment.

The UFMJRA applies to any foreign judgment for money damages that is final and conclusive and enforceable where rendered, even though subject to appeal. ${ }^{156}$ Under the UFMJRA, a foreign judgment "is enforceable in the same manner as the judgment of a sister state which is entitled to full faith and credit," unless one of the UFMJRA's grounds for non-recognition applies. ${ }^{157}$ The references to "sister state" judgments and "full faith and credit" are significant because they appear to incorporate an important aspect of enforcement of sister state judgments under the Full Faith and Credit Clause of the Constitution; i.e., that the enforcement court cannot review the merits of an otherwise valid judgment rendered in another state. ${ }^{158}$

The grounds for mandatory non-recognition of a foreign judgment under the UFMJRA are that the foreign court lacked personal or subject matter jurisdiction, or "the judgment was rendered under a system which does not provide impartial tribunals or procedures compatible with the requirements of due process of law."159 In addition, a foreign judgment need not be recognized based on several other specified grounds, including that the defendant did not receive proper notice of the foreign court proceeding, or that the cause of action upon which the judgment is

154. E.g., Soc'y of Lloyd's v. Reinhart, 402 F.3d 982, 999 (10th Cir. 2005), cert. denied, 126 S. Ct. 366 (2005) (applying Utah's common law principles of comity, which are similar to the provisions of the UFMJRA); Alberta Sec. Comm'n v. Ryckman, 30 P.3d 121, 126-27 (Ariz. App. 2001) (applying the Restatement as Arizona's common law recognition doctrine); Petition of Breau, 565 A.2d 1044, 1049-50 (N.H. 1989) (relying on the Restatement to determine recognition of foreign judgment). See Restatement (ThIRD) OF Foreign RELATIONS LAW §§ $481 \& 482$ (1987 \& Supp. 2007) (collecting cases); Brand, supra note 147, at 264-83 (comparing the UFMJRA's and the Restatement's recognition standards).

155. Pursuant to the command of Erie, a federal court must also apply state law when determining whether to recognize or enforce a foreign judgment. E.g., Resolution Trust Corp. v. Ruggiero, 994 F.2d 1221, 1226 (7th Cir. 1993); Success Motivation Inst. of Japan, Ltd. v. Success Motivation Inst., Inc., 966 F.2d 1007, 1009-10 (5th Cir. 1992); McCord v. Jet Spray Int'l Corp., 874 F. Supp. 436, 438 (D. Mass. 1994).

156. Unif. Foreign Money-Judgments ReCognition ACt § 2, 13 U.L.A. (Part II) 46.

157. Id. at $\S 3$.

158. See Fauntleroy v. Lum, 210 U.S. 230 (1908).

159. $§ 4(\mathrm{a})$. 
based is repugnant to the public policy of the enforcement state. ${ }^{160}$ Finally, the UFMJRA sets forth a non-exclusive list of the proper bases for the assertion of personal jurisdiction over a defendant by a foreign court, generally tracking the Supreme Court's various holdings under the Due Process Clause. ${ }^{161}$

Most of the provisions of the UFMJRA do not come into play when a plaintiff seeks to enforce a foreign judgment rendered after the plaintiff's action was dismissed by a U.S. court based on forum non conveniens. In this context, questions concerning the foreign court's exercise of personal jurisdiction or subject matter jurisdiction, or regarding proper service of process on the defendant, are usually irrelevant. Recall that in order to grant a forum non conveniens dismissal, a U.S. court must first find that a foreign court is jurisdictionally "available." ${ }^{\text {"62 }}$ To satisfy this prerequisite, each defendant typically agrees to submit to the personal jurisdiction of the foreign tribunal and to accept service of process, and the court usually conditions the dismissal on the defendant's fulfillment of these agreements. ${ }^{163}$

The two grounds for non-recognition under the UFMJRA that are relevant are: (1) whether the judgment was rendered under a system that comports with due process of law, and (2) whether the foreign judgment is repugnant to the public policy of the state in which the enforcement court sits. ${ }^{164}$ These two grounds are discussed below in the context of a foreign judgment rendered pursuant to a foreign country's statutes, such as those adopted by the Commonwealth of Dominica or by Nicaragua, that are designed to counter the effect of a forum non conveniens dismissal.

\footnotetext{
160. Id. § 4(b). A 2005 revision to the Act adds two new discretionary grounds for nonrecognition: "the judgment was rendered in circumstances that raise substantial doubt about the integrity of the rendering court with respect to the judgment" and "the specific proceeding in the foreign court leading to the judgment was not compatible with the requirements of due process of law." Unif. Foreign-COUntry MONEy Judgments ReCOGNition ACT §§ 4(c)(7) \& (8), 13 U.L.A. (Part II) 11 (Supp. 2007).

161. UNIF. ForEIGN MONEY-JUdGMENTS RECOGNITION ACT $\S 5$.

162. See supra notes 34-38 and accompanying text.

163. See supra notes $36-37$ and accompanying text.

164. $\S 4$.
} 


\section{B. Enforcement of a Foreign Money Judgment Rendered Pursuant to Retaliatory Legislation Designed to Counter Forum Non Conveniens Dismissals: Due Process Considerations}

Let us assume that several residents of the Commonwealth of Dominica commenced a products liability action in a U.S. court against a U.S. defendant seeking damages for their personal injuries sustained in Dominica. The court subsequently dismisses the action based on forum non conveniens, expressly conditioned on the defendant's agreement to submit to the jurisdiction of the Dominican courts and accept service of process. The dismissal order contains a return jurisdiction clause, but does not require the defendant to pay any judgment that may be rendered by a Dominican court. ${ }^{165}$

After the dismissals, the plaintiffs file a products liability action against the defendant in a Dominican court, seeking compensatory and punitive damages. Pursuant to the Transnational Cause of Action (Product Liability) Act, the Dominican court asserts jurisdiction and indicates it will apply strict liability law of tort and calculate compensatory damages based on Dominican common law, but will award punitive damages, if appropriate under the standards set forth in the Act, in amounts based on U.S. decisions in similar cases. ${ }^{166}$ Service of process on the defendant is accomplished in accordance with Dominican law.

The defendant does not appear because, among other reasons, it is unwilling to post a bond in the amount of $140 \%$ of the amounts proved by the plaintiffs to have been awarded in similar proceedings in U.S. courts. Subsequently, the Dominican court enters a default judgment for the plaintiffs in the amount of $\$ 129$ million for compensatory damages and $\$ 140$ million for punitive damages. Because the defendant has no

165. If the defendant agrees to pay any judgment that may be rendered by a Dominican court as a condition of the forum non conveniens dismissal, potential enforcement problems may become moot. However, a problem could still arise if the Dominican court renders a judgment for the plaintiff but the defendant refuses to pay it. The fact that the defendant did not honor its agreement may simply mean that the dismissal is negated, and the plaintiff can proceed anew in the U.S. court. Obviously, this is not an attractive option for the plaintiff, who may now have to litigate the case all over again. Instead, the plaintiff would likely ask the court to recognize and enforce the Dominican judgment pursuant to the UFMJRA or, more directly, ask the court to enforce the defendant's initial agreement in a breach of contract action, perhaps based on some type of promissory estoppel theory.

166. The Dominican court in our hypothetical could also undertake a choice of law analysis under section 7(2) of the Act and conclude that another country or state, California for example, has the "most significant relationship to the cause of action and the parties." Based on that determination, section 7(2) would seem to authorize the Dominican court to apply California's law of tort liability, and of compensatory and punitive damages, in the action. See McDowell, supra note 78 , at $127-28$. 
assets located within Dominica, the plaintiffs now wish to enforce their judgment against the defendant in the United States. They file an enforcement action in the appropriate state or federal court where the defendant resides.

The defendant opposes this enforcement action and argues that, under the UFMJRA, the Dominican judgment should not be recognized by a U.S. court. The defendant bases this objection on two arguments: (1) the foreign judgment was rendered under a system that does not comport with due process of law; and (2) is repugnant to the public policy of the state in which the enforcement court sits. ${ }^{167}$ The proper resolution of these arguments requires some general observations regarding these two grounds for non-recognition of a foreign judgment.

\section{Foreign Court Procedures Must Be Compatible with Fundamental Due Process}

As explained above, the UFMJRA mandates non-recognition of a foreign judgment if the judgment was rendered under a system which does not provide "impartial tribunals or procedures compatible with the requirements of due process of law." "168 This provision gives rise to two related questions. First, under what circumstances should a U.S. court find that a foreign country's legal system does not provide impartial tribunals? Second, what criteria should a U.S. court employ to determine

167. § 4. Because the defendant never appeared in the Dominican proceedings and was served pursuant to Dominican law, the defendant could perhaps also argue that it did not receive adequate notice and that the Dominican court lacked personal jurisdiction. In other words, despite the defendant's agreement to submit to the jurisdiction of the Dominican courts and to accept service of process that was incorporated into the prior forum non conveniens dismissal order, the defendant did not actually comply with these conditions of the dismissal order. However, the defendant's agreement to submit to the jurisdiction of a Dominican court operates as a forum selection clause with respect to the subject matter of the litigation. Under the UFMJRA, this agreement constitutes a proper basis for the assertion of personal jurisdiction by a foreign court. $\S 5(\mathrm{a})(3)$. Likewise, assuming that the defendant did receive notice of the Dominican proceedings in time to defend, the fact that service was pursuant to Dominican law should be irrelevant to the enforcement action. $\S$ 4(b)(1).

Of course, the failure to submit to the jurisdiction of the Dominican court and to accept service may also be viewed as a breach of the conditional dismissal, thereby permitting the plaintiffs to return to the U.S. court that had previously entered the forum non conveniens dismissal and renew their litigation there.

168. $\S 4(\mathrm{a})(1)$. The fact that a foreign judgment is a default judgment does not preclude its recognition under the UFMJRA. See, e.g., Soc'y of Lloyd's v. Reinhart, 402 F.3d 982, 1005 (10th Cir. 2005) (enforcing default judgment entered by English court); Violeta I. Balan, Recognition and Enforcement of Foreign Judgments in the United States: The Need for Federal Legislation, 37 J. MARSHALL L. REV. 229, 248-49 (2003) (noting that the UFMJRA does not distinguish between default and contested judgments). 
whether a foreign country's litigation procedures are compatible with the requirements of due process of law?

As to the question of impartiality, the appropriate inquiry is whether the judicial system is an independent branch of the foreign country's government and is capable of administering, and does in fact administer justice in a fair manner. ${ }^{169}$ This post-judgment inquiry is very similar to the threshold "adequate forum" inquiry under the doctrine of forum non conveniens. ${ }^{170}$ Only where a foreign tribunal is specifically proven to be corrupt, or biased and incapable of acting impartially with respect to the defendant, should a U.S. court find that the foreign legal system lacks impartiality. ${ }^{171}$ Applying this standard to the facts of our hypothetical Dominican judgment, unless the defendant presents specific evidence that the Dominican tribunal (or a court in Nicaragua, if the judgment had been rendered there pursuant to Special Law No. 364) took bribes or was otherwise corrupt when it entered the judgment against defendant, an enforcement court should reject this grounds for non-recognition. ${ }^{172}$

The criteria for determining whether a foreign country's litigation procedures are "compatible with the requirements of due process" overlap, to some degree, those employed in the impartiality inquiry. In analyzing this statutory reference, some possible interpretations can be eliminated. This language does not refer to two very important requirements of due process in U.S. civil procedure-proper personal jurisdiction and adequate notice-because those requirements are specifically identified as grounds for non-recognition in other sections of the UFMJRA. ${ }^{173}$ Nor does this basis for non-recognition mean that a foreign country's procedures must incorporate all the specific due process requirements reflected in procedures in U.S. courts. ${ }^{174}$ If it did,

169. S.C. Chimexim S.A. v. Velco Enter., Ltd., 36 F. Supp. 2d 206, $213-15$ (S.D.N.Y. 1999) (finding Romanian court system provided impartial tribunals).

170. See supra notes 39-56 and accompanying text.

171. See, e.g., Bridgeway Corp. v. Citibank, 201 F.3d 134, 137-38, 142-44 (2d Cir. 2000) (refusing to enforce Liberian judgment because Liberia's judicial system is in disarray and the Constitution concerning judiciary no longer followed); see also Bank Melli Iran v. Pahlavi, 58 F.3d 1406, 1410-13 (9th Cir. 1995) (refusing to enforce Iranian judgment against sister of Shah of Iran because after the Shah was deposed, the Iranian judicial system could not provide her fair treatment or basic due process).

172. Most courts treat the various grounds for non-recognition as an affirmative defense that must be proven by the defendant. See Bank Melli, 58 F.3d at 1409 (collecting cases).

173. See supra notes $159-61$ and accompanying text.

174. See infra notes 175-76. According to the drafters of the UFMJRA, "a mere difference in the procedural system is not a sufficient basis for non-recognition. A case of serious injustice must be involved." See $\S 4 \mathrm{cmt}$. See Ingersoll Milling Machine Co. v. Granger, 833 F.2d 680, 688 (7th Cir. 1987) (noting that the UFMJRA does not require that the procedures employed by a foreign tribunal be identical to those employed in American courts); Brand, supra note 147, at 271 
few if any foreign judgments would be recognized because very few countries offer all the procedural safeguards viewed by U.S. courts as due process requirements in domestic litigation. ${ }^{175}$

Most courts interpret this reference to "due process" to mean only that foreign procedures must be "fundamentally fair" and not offend against "basic fairness." "176 Although these courts often fail to clearly delineate what procedures are essential to fundamental fairness, they do identify those procedures that are not essential. Foreign judgments have been enforced, for example, even though the foreign procedure did not include the right to cross-examine witnesses ${ }^{177}$ prohibited the defendant from raising certain defenses and counterclaims, ${ }^{178}$ prohibited discovery

(observing that foreign courts need not have procedures identical to U.S. courts to comply with due process requirements). See also infra notes 175-76.

175. See Soc'y of Lloyd's v. Turner, 303 F.3d 325, 330 (5th Cir. 2002) (ruling that foreign proceedings need not comply with the traditional rigors of American due process); Soc'y of Lloyd's v. Ashenden, 233 F.3d 473, 478 (7th Cir. 2000) (observing that very few foreign judgments would be enforced if the system had to confirm to the specifics of the American doctrine of due process). The drafters of the UFMJRA commented that the language of the UFMJRA was intended to embody the rule stated in Hilton v. Guyot, 159 U.S. 113, 205 (1895), where the Supreme Court pointedly noted that a French judgment for plaintiffs could be recognized even though a plaintiff was permitted to testify not under oath and was not subject to cross examination. $\S 4 \mathrm{cmt}$. See Ingersoll, 833 F.2d at 688, n.4; see also Brand, supra note 147, at 271 (noting that where personal jurisdiction exists, procedures different from those in the U.S. enforcing court will not generally rise to the level of a violation of due process in the enforcement of a foreign judgment).

176. E.g., Ashenden, 233 F.3d at 477 (observing it has been interpreted to mean "that the foreign procedures are 'fundamentally fair' and do not offend against 'basic fairness"'); Turner, 303 F.3d at 330 (noting "that foreign procedures [must only be] 'fundamentally fair' and ... not offend against 'basic fairness"'); Ingersoll, 833 F.2d at 686-88 (noting foreign procedures must be fundamentally fair and have basic fairness); Kam-Tech Sys. Ltd. v. Yardeni, 774 A.2d 644, 651 (N.J. Super. Ct. App. Div. 2001) (stating "that the foreign procedures are 'fundamentally fair' and do not offend against "basic fairness"). Some courts even call this the "international concept of due process" to distinguish it from the complex understanding of due process that has emerged in U.S. courts. E.g., Ashenden, 233 F.3d at 477 (calling it the "international concept of due process"); Soc'y of Lloyds v. Webb, 156 F. Supp. 2d 632, 641 (N.D. Tex. 2001), aff'd, 303 F.3d 325, 330 (5th Cir. 2002) (using the "international concept of due process" label). See Montré D. Carodine, Political Judging: When Due Process Goes International, 48 WM. \& MARY L. REV. 1159, 1183 (2007) ("The foreign system's procedures need only be 'fundamentally fair' and not offend 'basic fairness."'). These courts emphasize that this "international due process" is a less stringent due process than is required under American jurisprudence. Ashenden, 233 F.3d at 477; Webb, 156 F. Supp. $2 \mathrm{~d}$ at 641.

177. See Hilton v. Guyot, 159 U.S. 113, 204-05 (1895) (noting that French procedures that admitted hearsay and permitted testimony not under oath, and that denied defendants the right to cross-examine witnesses, did not constitute a public policy violation); Ingersoll, 833 F.2d at $686-88$ (enforcing Belgian judgment despite limitations on defendant's ability to call and cross-examine witnesses in Belgian proceedings); Panama Processes v. Cities Serv. Co., 796 P.2d 276, 285 (Okla. 1980) (enforcing Brazilian judgment despite absence of right of cross-examination in the Brazilian court).

178. See Ashenden, 233 F.3d at 479-80 (enforcing an English Court's decision that "held that the names had waived their procedural rights in advance"); Soc'y of Lloyd's v. Mullin, 255 F. Supp. 2d 468, 472-73 (E.D. Pa. 2003), aff'd, 96 Fed. Appx. 100, 103-04 (3d Cir. 2004) (observing that English Courts "prohibited Mullin from raising certain defenses and counterclaims"); Webb, $156 \mathrm{~F}$. Supp. 2d at 639-41 (ruling that names had waived those defenses). 
as to the amount claimed by the plaintiff, ${ }^{179}$ lacked a verbatim transcript, ${ }^{180}$ or conditioned leave to defend on the deposit of an amount equal to the prayer in the complaint. ${ }^{181}$ Also, this basis for nonrecognition apparently refers only to the requirements of procedural, not substantive, rights. ${ }^{182}$ The only substantive basis that the UFMJRA recognizes for non-enforcement of a foreign judgment is that the judgment is repugnant to the public policy of the enforcing state. ${ }^{183}$

This "compatible with the requirements of due process" inquiry is very similar to the threshold inquiry under forum non conveniens as to whether an alternative forum is "adequate," except now the inquiry is from the defendant's perspective. ${ }^{184}$ Under both inquiries, where the foreign legal system is not corrupt or biased but is procedurally different, a court should conclude that the lack of beneficial litigation procedures similar to those available in U.S. courts does not render the foreign forum "inadequate" or the foreign tribunal's procedures incompatible with the requirements of due process. ${ }^{185}$

The similarities in these two inquiries raise an interesting estoppel question: Should a court's finding that a foreign forum is "adequate" for purposes of forum non conveniens preclude a subsequent enforcement court, on the basis of either collateral or judicial estoppel, from finding that the same foreign forum lacked impartiality or procedures compatible with due process? Collateral estoppel may not apply because the ex ante "adequacy" determination in the context of forum non conveniens may be considered a different issue than the post hoc "compatible-with-dueprocess" determination in the enforcement context. ${ }^{186}$ Even if the facts

179. See, e.g., Ashenden, 233 F.3d at 480 (observing "no right to pretrial discovery"); Panama Services, 796 P.2d at 285 (noting the parties in Brazil may not conduct pre-trial discovery).

180. British Midland Airways, Ltd. v. Int'l Travel, Inc., 497 F.2d 869, 871 (9th Cir. 1974); Tonga Air Sers. v. Fowler, 826 P.2d 204, 212 (Wash. 1992).

181. British Midland, 497 F.2d at 870-71.

182. Ashenden, 233 F.3d at 480.

183. Id. The "public policy" exception to recognition is discussed infra notes 244-68 and accompanying text.

184. See supra notes $39-56$ and accompanying text.

185. For enforcement cases, see supra notes 174-81. For forum non conveniens cases, see, e.g., Satz v. McDonnell Douglas Corp., 244 F.3d 1279, 1283 (11th Cir. 2001) (finding "the district court did not abuse its discretion in finding that Argentina is an adequate forum"); Aguinda v. Texaco, 303 F.3d 470, 477-79 (2d Cir. 2002) (finding that Ecuador was an adequate forum); Delgado v. Shell Oil Co., 890 F. Supp. 1324, 1356-66 (S.D. Tex. 1995), aff'd, 231 F.2d 165 (5th Cir. 2000) (ruling that Burkina Faso, Costa Rica, Dominica, Ecuador, Guatemala, Honduras, Ivory Coast, Nicaragua, Panama, The Philippines, Saint Lucia, and Saint Vincent were adequate forums). See also Dunham \& Gladbach, supra note 1, at 675-78 (reviewing forum non conveniens cases); Waples, supra note 35 , at $1485-1501$ (same).

186. Collateral estoppel applies where the issue in the current proceeding is identical to the issue actually litigated and determined in the prior action. See ReSTATEMENT (SECOND) OF JUDGMENTS $\S$ 
do not permit the use of collateral estoppel, there is a strong argument for the application of judicial estoppel, or preclusion against inconsistent positions, which is designed to protect the integrity of the courts and the judicial process. ${ }^{187}$

The doctrine of judicial estoppel prevents a party from asserting a factual position in a legal proceeding that is contrary to a position previously taken by him in a prior legal proceeding. ${ }^{188}$ A defendant who prevails in a forum non conveniens motion by presenting facts that establish the "adequacy" of an alternative forum should be precluded from attacking the fairness of that judicial system when the plaintiff subsequently seeks to enforce the foreign judgment in a U.S. court. Otherwise, as one court put it, the defendant would be permitted "to 'play fast and loose' with courts of justice according to the vicissitudes of self-interest." 189

2. Is the Pre-Appearance Bond Requirement Compatible with Due Process?

Dominica's retaliatory legislation requires, as a condition of appearance, that the defendant post a bond in the amount of $140 \%$ of the possible recovery. The defendant in our hypothetical did not appear and post this bond. Consequently, the Dominican court entered a default judgment. Does this pre-appearance bond requirement, which, in effect, may only apply to a U.S. defendant after a forum non conveniens dismissal from a U.S. court, mean that the judgment was rendered under a legal "system that does not provide impartial tribunals or procedures compatible with due process of law?" There are two constitutional concerns. First, does requiring the defendant to post a substantial bond

27 (1982) ("When an issue of fact or law is actually litigated and determined by a valid and final judgment... the determination is conclusive ...."). Even when there is a lack of total identity between the matters involved in the two proceedings, the overlap may be so substantial that preclusion is appropriate. Id. cmt. c. The evidentiary overlap between the "adequacy" and the subsequent "fairness" determinations may well be sufficient in some cases to permit the use of collateral estoppel.

187. See, e.g., Bridgeway Corp. v. Citibank, 201 F.3d 134, 141-44 (2d Cir. 2000) (ruling defendant not judicially estopped from raising objection to the fairness of Liberian courts in judgment enforcement proceeding even though defendant voluntarily participated in the Liberian litigation); Guinness PLC v. Ward, 955 F.2d 875, 898-900 (4th Cir. 1992) (applying judicial estoppel to preclude defendant from raising alleged post judgment settlement of British judgment in an enforcement proceeding).

188. See, e.g., Bridgeway, $201 \mathrm{~F} .3 \mathrm{~d}$ at 141 (requiring a "clear inconsistency" between the present and former positions); Guinness, 955 F.2d at 899 (observing that "a party cannot have its cake and eat it too").

189. Guinness, 955 F. 2d at 899. 
as a condition to participation in litigation deny access to court in violation of due process? Second, does the imposition of a preappearance bond without an opportunity for a prior hearing to contest the amount of the bond violate procedural due process?

Typically, of course, a party is not required to post a bond as a condition of participation in civil litigation in U.S. courts. But this concept is not completely foreign to American jurisprudence. ${ }^{190}$ For example, most states have adopted statutes requiring an unlicensed foreign or alien insurer, before it can defend any action initiated against it, to deposit with the court security in the amount of any judgment that might be rendered against it. ${ }^{191}$ If the defendant insurer fails to deposit the specified security, the trial court will strike its answer and enter a default judgment. ${ }^{192}$ Although some state statutes authorize the court to dispense with the security if the insurer maintains sufficient funds in the state to satisfy any judgment, others do not provide their courts such authority. ${ }^{193}$ The amount of the security required varies with each case, but bonds of several million dollars are not uncommon. ${ }^{194}$

190. See, e.g., Lindsey v. Normet, 405 U.S. 56, 77-78 (1972) (holding state requirement that tenants seeking to appeal an eviction judgment must post double-bond in addition to the ordinary security for an appeal discriminates against poor tenants in violation of the Equal Protection Clause); Bell v. Burson, 402 U.S. 535, 539 (1971) (holding unconstitutional a state statute under which an uninsured motorist involved in an automobile accident faced suspension of his driver's license unless he posted security sufficient to cover the amount of damages claimed); Cohen v. Beneficial Indus. Loan Corp., 337 U.S. 541, 551-52 (1949) (upholding constitutionality of state law requirement that plaintiff filing a shareholders derivative action in federal court must post security for payment of defense expenses); Ownbey v. Morgan, 256 U.S. 94, 112-13 (1921) (upholding constitutionality of state attachment procedure that required defendants to post security as a condition precedent to entering an appearance and defending the merits); Beaudreau v. Superior Court, 535 P.2d 713, 724 (Cal. 1975) (holding state requirement that plaintiffs filing suit against a public entity must post an undertaking as security for costs, without notice and a prior hearing, violates the Due Process Clause).

191. See Kirill P. Strounnikov, Pre-Appearance Security Requirements for Unlicensed Reinsurers in the United States, 7 CONN. INS. L.J. 465, 467-68 (2001) (indicating that forty-five states have adopted security-posting statutes); Christopher Hitchcock \& Peter J. Biging, Tactical Use of State Laws Requiring Unauthorized Insurers to Post Preanswer Security, 31 TORT \& INS. L.J. 767, 767-68 n.2 (1996) (citing forty-three state statutes). Although under these statutes "foreign" refers to an insurer from another state and "alien" to an insurer from another country, Strounnikov, supra, at $467 \mathrm{n} .4$, this article uses "foreign" to refer to any non-resident insurer.

192. Strounnikov, supra note 191 , at 470.

193. Id. at 470-73.

194. See, e.g., Lakehead Pipe Line Co. v. Am. Home Assur. Co., 981 F. Supp. 1205, 1209 (D. Minn. 1997) (ordering bond of $\$ 16,329,750.00$ ); Int’l Surplus Lines Ins. Co. v. Certain Underwriters \& Underwriting Syndicates at Lloyd's of London, 868 F. Supp. 923, 926 (S.D. Ohio 1994) (requiring defendant reinsurers to post security in the amount of losses alleged to total $\$ 72,707,635.70$, subject to proof that such losses were paid by plaintiff insurers); Levin v. Intercont'1 Cas. Ins. Co., 742 N.E.2d 109, 110 (N.Y. 2000) (affirming pre-answer bond of \$4,835,333.99); Curiale v. Ardra Ins. Co., 667 N.E. 2d 313, 314 (N.Y 1996) (affirming order striking defendant's answer for failure to post pre-appearance bond of \$10,351,877.38); Hitchcock \& Biging, supra note 
Foreign insurers who suffered default judgments because they were financially unable to post the security have challenged this pre-answer security requirement as a violation of due process. ${ }^{195}$ So far, these challenges have not been successful. At least three courts have concluded that a state's imposition of a pre-answer security requirement does not violate the Due Process Clause. ${ }^{196}$ However, these decisions suggest that a pre-appearance bond requirement in the context of a transnational tort action does present significant due process issues.

One issue is whether the entry of a default judgment against a defendant who is financially unable to post pre-appearance security in the amount set by the trial court denies that defendant access to court in violation of due process. This argument relies on such cases as Boddie $v$. Connecticut, ${ }^{197}$ where the Supreme Court held a state statute that required indigent plaintiffs to pay filing fees in order to seek a divorce denied them court access in violation of the Due Process Clause. ${ }^{198}$ However, subsequent decisions have limited Boddie's reach to those situations where the state provides the exclusive means for resolving a dispute regarding a fundamental interest, like dissolution of marriage. ${ }^{199}$ For example, in United States v. Kras, ${ }^{200}$ the Supreme Court concluded that the imposition of filing fees on indigent petitioners in bankruptcy, and the requirement of payment of these fees as a precondition to discharge in voluntary bankruptcy, did not violate the Due Process Clause because denial of access to bankruptcy court does not implicate a fundamental interest and does not preclude petitioners from seeking other methods of relief from debts. ${ }^{201}$

Likewise, courts have rejected this due process argument in the context of a pre-answer security imposed on unlicensed foreign insurers,

191, at 771 n.15 (collecting cases).

195. E.g., British Int'l Ins. Co. v. Seguros La Republica, S.A., 212 F.3d 138, 139 (2d Cir. 2000); Trihedron Int'l Assurance, Ltd. v. Superior Court, 267 Cal. Rptr. 418, 420 (Cal. Ct. App. 1990); Curiale, 667 N.E.2d at 314. See Hitchcock \& Biging, supra note 191, at 771-72 n.17 (collecting cases).

196. British Int'l Ins., 212 F.3d at 142-44; Trihedron, 267 Cal. Rptr. at 425-26; Curiale, 667 N.E.2d at 319 .

197. 401 U.S. 371 (1971).

198. Id. at 380-81.

199. E.g., Orwein v. Schwab, 410 U.S. 656, 658-59 (1973) (upholding constitutionality of state requirement that welfare recipient pay filing fee when appealing reduction in benefits because interest in increased welfare payments has far less constitutional significance than the marital interests in Boddie); United States v. Kras, 409 U.S. 434, 443-44 (1973) (ruling imposition of filing fees in bankruptcy action did not affect a fundamental interest such as the marital relationship and associational interests in Boddie).

200. 409 U.S. 434 (1973).

201. Id. at $443-50$. 
and with respect to court access bonds in other types of financial claims litigation. ${ }^{202}$ The same result is likely in a transnational tort action, such as our hypothetical Dominican case. Assuming the defendant in a transnational tort action has insufficient funds to cover the cost of a preappearance bond - an assumption, in most cases, that does not reflect reality - the subject of the litigation is financial compensation and not a fundamental interest. Moreover, an action in court is not the exclusive means available for resolving such a dispute. The defendant is free to resolve a transnational tort claim through settlement and release, without the necessity of litigation.

The second issue is whether a pre-appearance bond imposed without a prior hearing violates the defendant's right to procedural due process. Here, the traditional due process test articulated by the Supreme Court in Mathews v. Eldridge $e^{203}$ and Connecticut v. Doehr ${ }^{204}$ applies. Under this test, the court must balance the private interests involved, the risk of erroneous deprivation of that interest through the procedures utilized, the probable value of additional procedural safeguards, and the interest of the party seeking the prejudgment remedy with, nonetheless, due regard for any ancillary interest the government may have in providing the procedure or forgoing the added burden of providing greater protections. ${ }^{205}$ If the balance weighs in favor of the defendant, the trial court must provide the defendant an opportunity for a hearing prior to imposition of the pre-appearance bond. ${ }^{206}$

In three instances, courts applying the Mathews/Doehr test to statutes that require an unlicensed foreign insurer to post security as a precondition to filing an answer have concluded this requirement does not deprive the defendant insurer of procedural due process. ${ }^{207}$ However, in two of these cases the challenged statute provided the defendant

202. See Curiale, 667 N.E.2d at 316-18 (upholding pre-answer security requirement despite argument that the entry of default judgment against a defendant insurer who is financially unable to post security in the amount set by the trial court deprives the defendant of due process of law).

203. 424 U.S. 319 (1976).

204. 501 U.S. 1 (1991).

205. Id. at 10-11. See British Int'1 Ins. Co. v. Seguros La Republica, S.A., 212 F.3d 138, 142 (2d Cir. 2000) (summarizing the Mathews/Doehr due process test).

206. See, e.g., Doehr, 501 U.S. at 14-16 (concluding prejudgment attachment of real property without prior notice and a hearing violated due process); Mitchell v. W. T. Grant Co., 416 U.S. 600 , 604-05 (1974) (upholding constitutionality of an ex parte prejudgment sequestration process that provided for immediate post-deprivation hearing, and required a judge rather than a clerk to determine that there is a clear showing of entitlement to the writ based on a detailed affidavit); Fuentes v. Shevin, 407 U.S. 67, 96 (1972) (finding unconstitutional state replevin provisions that permitted vendors to have goods seized through an ex parte application to a court clerk).

207. E.g., British Int'l Ins., 212 F.3d 138; Curiale, 667 N.E.2d 313; Trihedron, 267 Cal. Rptr. 418 
insurer with notice and an opportunity to be heard on the appropriate amount of the required pre-answer security prior to its impostition. ${ }^{208}$ In the third case, the court upheld the imposition of pre-answer security without prior notice and a hearing because the governmental interest in protecting the states' insureds and beneficiaries outweighed the insurer's less significant property interest. ${ }^{209}$ The reasoning employed by these courts suggests a pre-appearance bond requirement in the context of a transnational tort action, imposed without notice and a prior hearing, presents a serious due process issue.

A pre-appearance bond is the functional equivalent of a prejudgment attachment because it forces the defendant to place some of its assets in the hands of the court, during which time the defendant has no access to those assets. ${ }^{210}$ Consequently, the bond requirement constitutes the deprivation of a significant property interest, within the meaning of the Mathews/Doehr balancing test. ${ }^{211}$ The plaintiff's and the government's interest in requiring a pre-appearance bond is also substantial in the foreign insurer and transnational tort contexts. This substantial interest is " "ensuring the availability of funds from which a judgment against a foreign [defendant] may be promptly paid, instead of requiring claimants to resort to far-flung forums for satisfaction of their judgments." 212 However, the risk of erroneous deprivation of the defendant's property rights is much higher in transnational tort litigation than in the unlicensed foreign insurer cases.

In the typical unlicensed insurer case, the plaintiff insured is suing a foreign insurer for breach of contract for failure to pay a claim under an insurance policy. ${ }^{213}$ The resolution of the central issues ordinarily involves "uncomplicated matters that lend themselves to documentary

208. See Curiale, 667 N.E.2d at 319 (holding "appellant has received all of the due process protections required by the circumstances"); British Int'l Ins. Co., 212 F.3d at 143-44 (stating notice was a regulatory requirement).

209. Trihedron, 267 Cal. Rptr. at $425-26$.

210. British Int'l Ins., 212 F.3d at 141-42; Stephens v. National Distillers \& Chem. Corp., 69 F.3d 1226, 1229 (2d Cir. 1995).

211. British Int'l Ins., 212 F.3d at 141-42; see Doehr, 501 U.S. at 11-12 (finding that the temporary or partial impairment of defendant's property rights caused by a prejudgment attachment affects a significant property interest).

212. British Int'l Ins., 212 F.3d at 143 (quoting Curiale, 667 N.E.2d at 319). See, e.g., Trihedron, $267 \mathrm{Cal}$. Rptr. at 423 (noting state's strong interest in ensuring that resident insureds are not left to seek redress in "distant forums where they will be, for practical purposes, without remedy"); Lakehead Pipe Line Co. v. Am. Home Assurance Co., 981 F. Supp. 1205, 1208-09 (D. Min. 1997) (identifying state's interest as removing the "insuperable obstacle of resorting to distant forums for the purpose of asserting legal rights under [insurance] policies").

213. E.g., Trihedron, 267 Cal. Rptr. at 420; Lakehead Pipe, 981 F. Supp. at 1208; Ace Grain Co. v. Am. Eagle Fire Ins. Co., 95 F. Supp. 784, 785-86 (S.D.N.Y. 1951). 
proof, 214 thereby making the risk of error by the trial court relatively minimal when determining the appropriate amount of the pre-answer security. ${ }^{215}$ In contrast, a transnational tort case, such as our hypothetical products liability action in a Dominican court, involves issues of causation and damages whose resolution will be based on testimony, not documents. Assuming the court will assess the plaintiff's likelihood of success on these issues when determining the appropriate amount of a pre-appearance bond, the risk of error is quite high if the court relies only on the plaintiff's one-sided presentation. ${ }^{216}$ Accordingly, the imposition of the bond without input from the defendant-input that can come only through some type of adversarial proceeding - may well deprive the defendant of its right to procedural due process as defined in Mathews and Doehr. ${ }^{217}$ Certainly, a defendant would have a reasonable chance of prevailing on this procedural due process issue if a pre-appearance bond were imposed ex parte by a U.S. court in a purely domestic products liability case. ${ }^{218}$

However, this due process analysis is far more subtle when applied to enforcement of a foreign judgment, as opposed to the validity of an ex parte pre-judgment attachment process employed by a U.S. court. As

214. Doehr, 501 U.S. at 14 (quoting Mitchell v. W. T. Grant Co., 416 U.S. 600, 609 (1974)).

215. See British Int'l Ins., 212 F.3d at 144 n.3 (noting plaintiff's claim that defendant owes a sum of money under insurance contracts "appears to fall into the category of cases cited in Doehr as 'lending themselves to accurate ex parte assessments of the merits' since they 'concern ordinarily uncomplicated matters that lend themselves to documentary proof"' (quoting 501 U.S. at 14, 17))

216. See Doehr, 501 U.S. at 14 (noting that a "judge could make no realistic assessment concerning the likelihood of [a tort action's] success based upon one-sided, self-serving, and conclusory submissions" of the plaintiff).

217. Cf. Bell v. Burson, 402 U.S. 535 (1971). In Bell, the Supreme Court required the suspension of the driver's license of an uninsured motorist involved in an accident unless he posted security to cover the amount of the damages claimed by the aggrieved parties in reports of the accident, without a hearing that includes consideration of the motorist's fault, denied the motorist procedural due process. $I d$. at 536. Addressing the nature of the procedural due process which must be afforded the licensee, the Bell court held "procedural due process will be satisfied by an inquiry limited to the determination whether there is a reasonable possibility of judgments in the amounts claimed being rendered against the licensee." $I d$. at 540. Bell's holding suggests that in order to satisfy due process in a domestic case, a pre-appearance bond such as that required by Dominica's Act must not only afford the defendants an opportunity for a prior hearing but also must provide the defendant an opportunity to contest whether there is a reasonable possibility the court will render a judgment in the amount sought by the plaintiff. See McDowell, supra note 78, at 121 (commenting that a fairer approach to imposition of a bond under Dominica's Transnational Act would require the judge to determine there is a prima facie case for trial); Anderson, supra note 10, at 204 (observing that the Transnational Act may require the plaintiff to prove he has a reasonable likelihood of success).

218. In Doehr, the Supreme Court held that a state prejudgment attachment procedure which permitted the plaintiff, in an intentional tort action, to attach defendant's real property without notice and an opportunity for a prior hearing violated procedural due process because, in part, the risk of erroneous deprivation was high. 501 U.S. at 19. 
explained above, the UFMJRA does not require a foreign judicial system to employ all the specific due process protections reflected in procedures in U.S. courts. ${ }^{219}$ Moreover, the UFMJRA focuses on whether a foreign country's judicial system as a whole provides "procedures compatible with the requirements of due process of law," and not whether the particular judgment sought to be enforced was issued in a proceeding that conformed to due process. ${ }^{220}$ Even under the recent revision to the UFMJRA, which provides a discretionary ground for nonrecognition where the specific proceeding in the foreign court was not compatible with due process, enforcement is likely unless the defendant was denied fundamental due process. ${ }^{221}$

Consequently, a defendant may find it difficult to persuade a U.S. court not to recognize a Dominican judgment based solely on the absence of a prior hearing so long as the Dominican legal system is generally viewed as fundamentally fair, particularly if the Dominican court provides the defendant with some other means of challenging the

219. See supra notes $174-81$ and accompanying text.

220. E.g., Soc'y of Lloyd's v. Reinhart, 402 F.3d 982, 994-95 (10th Cir. 2005), cert. denied, 126 S. Ct. 366 (2005); Soc'y of Lloyd's v. Ashenden, 233 F.3d 473, 477-78 (7th Cir. 2000); Soc'y of Lloyd's v. Mullin, 255 F. Supp. 2d 468, 472 (E.D. Pa. 2003), aff'd, 96 Fed. Appx. 100, 103-04 (3d Cir. 2004); CIBC Mellon Trust Co. v. Mora Hotel Corp., 792 N.E.2d 155, 160 (N.Y. 2003), cert. denied, 540 U.S. 948 (2003).

In one analogous situation, the defendants in CIBC Mellon Trust Co. v. Mora Hotel Corp., argued that English money judgments totaling over $\$ 300$ million should not be enforced in New York because the English proceedings denied them due process of law. 792 N. E.2d at 159-60. The plaintiffs had commenced actions in the English court alleging multinational investment fraud by various foreign defendants. Id. at 157-58. Upon ex parte application of the plaintiffs, the English court had entered a "Mareva" injunction, where the defendant's assets would be frozen during the pendency of the proceedings. Id. When the defendants declined to comply with this injunction, they were debarred from defending against the plaintiffs' claims, which resulted in the English court's default judgments for plaintiffs in the amount of $\$ 330$ million. Id. at 158. The New York Court of Appeals rejected defendant's arguments for non-recognition and enforced the English judgment, ruling that the English judicial system provided procedures compatible with the requirements of due process of law within the meaning of New York's recognition of foreign judgments statute. Id. at 160. See also Guinness PLC v. Ward, 955 F.2d 875, 901 (4th Cir. 1992) (holding remedies granted in a Mareva injunction, though excessive by American notions, does not establish that the final judgment did not comport with the requirements of due process).

221. See Uniform Foreign-COUNTRY Money Judgments ReCOGNition Act $\S 4$ (c)(8) cmt. 12, 13 U.L.A. 11 (Supp. 2007) (commenting that the forum court may deny recognition if the court finds the specific proceeding in the foreign court was not compatible with the requirements of fundamental fairness); Ashenden, 233 F.3d at 478 (noting that even under the retail approach that considers whether the specific foreign proceeding giving rise to the judgment was compatible with due process, the international notion of due process applies, not the specifics of the American doctrine of due process). See also supra note 160. 
imposition and amount of the bond. ${ }^{222}$ Indeed, the court in one recent case expressed its disbelief that the UFMJRA

is intended to bar the enforcement of all judgments of any foreign legal system that does not conform its procedural doctrines to the latest twist and turn of our courts regarding, for example, the circumstances under which due process requires an opportunity for a hearing in advance of the deprivation of a substantive right rather than afterwards.

\section{Will a U.S. Court Enforce a Foreign Award of Punitive Damages?}

\section{a. A Judgment Containing an Award of Punitive Damages May Not Constitute a "Foreign Judgment" Within the Meaning of the UFMJRA}

Under the UFMJRA, a "foreign judgment means any judgment of a foreign state granting or denying recovery of a sum of money, other than a judgment for taxes, a fine or other penalty ...."224 The UFMJRA does not define the phrase "fine or other penalty." The few cases that interpret this language have endorsed the following test:

The question whether a statute of one State, which in some aspects may be called penal, is a penal law in the international sense, so that it cannot be enforced in the courts of another State, depends upon the question whether its purpose is to punish an offence [sic] against the public justice of the State, or to afford a private remedy to a person injured by the wrongful act. ${ }^{22}$

This test suggests that a foreign judgment for punitive damages obtained by a private litigant as opposed to a government entity does not constitute a judgment for a "fine or other penalty" within the meaning of

222. See supra note 116. An English judgment entered after the defendant failed to pay a deposit equal to the amount sought in the complaint was enforced in British Midland Airways, Ltd. $v$. Int'l Travel, Inc., 497 F.2d 869 (9th Cir. 1974), where the deposit was imposed after a hearing and appellate review.

The cost and judgment bonds authorized by Nicaragua's Special Law No. 364 present a more difficult due process question because they are set amounts required to be posted by the defendant as a condition to participation in the litigation, apparently without any opportunity to challenge whether the plaintiff's case is strong enough to warrant imposition of such onerous bonds. See supra notes 137-40 and accompanying text.

223. Ashenden, 233 F.3d at 476.

224. § 1(2).

225. Chase Manhattan Bank, N.A. v. Hoffman, 665 F. Supp. 73, 75 (D. Mass. 1987) (quoting Huntington v. Attrill, 146 U.S. 657, 673-74 (1892)); see also Desjardins Ducharme v. Hunnewell, 585 N.E.2d 321, 323 (Mass. 1992). 
the UFMJRA. ${ }^{226}$ Moreover, even if the UFMJRA were interpreted so as not to apply to a foreign judgment for punitive damages, recognition may still be possible on the basis of comity. ${ }^{227}$

\section{b. A Foreign Court's Award of Punitive Damages Must Comply with Due Process}

Even assuming a foreign judgment that includes an award of punitive damages is governed by the UFMJRA, or may be enforced as a matter of comity if not governed by the UFMJRA, a U.S. court will certainly review that award for compliance with the relevant constitutional limitations. The Due Process Clause prohibits a state from imposing a "grossly excessive" punishment on a tortfeasor. ${ }^{228}$ In determining whether damages awarded are reasonably necessary to vindicate the state's legitimate interests in punishment and deterrence, the court must apply three guideposts: (1) the degree of reprehensibility of the defendant's conduct; (2) the ratio of the punitive damages award to the actual harm inflicted on the plaintiff; and (3) the civil or criminal penalties that could be imposed for comparable misconduct. ${ }^{229}$ No one factor is dispositive - all three must be considered together in assessing the reasonableness of the award. ${ }^{230}$ For example, a defendant's egregiously improper behavior that causes personal injuries may justify a higher ratio of punitive to compensatory damages, even though normally a ratio of less than ten to one is considered constitutionally reasonable. ${ }^{231}$ However, although punitive damages may properly be imposed to further a state's legitimate interests in punishing unlawful conduct and deterring

226. See Restatement (Third) Foreign Relations Law (1987), § $483 \mathrm{cmt}$. b. Although some countries consider judgments penal for purposes of nonrecognition if punitive damages are awarded even when no governmental agency is a party, such judgments are not considered penal for this purpose in the United States. Id.

227. Cf. Uniform Foreign-COUNTRY MONEy Judgments ReCOGNition ACt $\S 7$ (providing that the "Act does not prevent the recognition of a foreign judgment in situations not covered by this Act”); Milhoux v. Linder, 902 P.2d 856 (Colo. Ct. App. 1995) (enforcing a Belgian judgment based on comity even though recognition is not required under Colorado's version of the UFMJRA due to reciprocity provision); Knothe v. Rose, 392 S.E.2d 570 (Ga. Ct. App. 1990) (holding Georgia's UFMJRA was inapplicable to a judgment for child support but the court had the power to enforce the judgment under the principle of comity); RESTATEMENT (THIRD) FOREIGN RELATIONS LAW (1987), $\S 483 \mathrm{cmt}$. a (indicating that nonrecognition of penal and tax judgments is not required but may be permitted).

228. BMW of N. Am., Inc. v. Gore, 517 U.S. 559, 568, 574-86 (1996); TXO Prod. Corp. v. Alliance Res. Corp., 509 U.S. 443, 454 (1993).

229. Gore, 517 U.S. at 574-75.

230. See id. at 574-86.

231. Id. at 582-83. 
its repetition, a state may not impose economic sanctions on violators of its laws with the intent of punishing or deterring the tortfeasor with respect to conduct in other jurisdictions that has no impact on the forum state or its residents. ${ }^{232}$

The Due Process Clause also requires the court system that awards punitive damages to include certain procedural safeguards. The factfinder must be provided clear instructions as to when an award of punitive damages is appropriate under the relevant law so that its discretion is not unlimited. ${ }^{233}$ If the fact-finder is a jury, the state must establish post-verdict procedures for scrutinizing the punitive award by the trial judge. ${ }^{234}$ A state must also afford the defendant an opportunity for appellate review to ensure "that the punitive damages are reasonable in their amount and rational in light of their purpose to punish what has occurred and to deter its repetition." 235

A court asked to enforce a foreign judgment awarding punitive damages must independently review it for compliance with all of these due process limitations. ${ }^{236}$ This review would determine whether the award is "grossly excessive," and whether the foreign court employed appropriate standards and procedures. Our hypothetical Dominican judgment would be enforced in the United States only if it survives such scrutiny. Although the determination of whether the amount of an award is "grossly excessive" will depend on the specific facts of each case, the low ratio of punitive to compensatory damages in our hypothetical judgment suggests it may not be constitutionally suspect, particularly in light of the nature of defendants' wrongful conduct and the seriousness of plaintiffs' injuries. ${ }^{237}$ Moreover, the Transnational Act requires a

232. Id. at 572-73. Moreover, the Due Process Clause does not permit a jury to base an award upon its desire to punish the defendant for harming persons who are not before the court. Philip Morris USA v. Williams, 127 S. Ct. 1057 (2007).

233. See, e.g., Haslip, 499 U.S. at 19-20 (concluding that the punitive damages awarded "were not violative of the Due Process Clause" because the jury instructions "gave the jury significant," but not unlimited, discretion).

234. See, e.g., id. at 20 (The Alabama Supreme Court established such post-verdict procedures via the Hammond test, which "ensures meaningful and adequate review by the trial court whenever a jury has fixed the punitive damages.").

235. Id. at 21; see also Honda Motor Co. v. Oberg, 512 U.S. 415, 432 (1994) (finding that Oregon's denial of judicial review of punitive damages awards violated due process because it "removed that procedural safeguard without providing any substitute procedure and without any indication that the danger of arbitrary awards ha[d] in any way subsided over time.").

236. To the extent that these due process limitations on the amount of the award are substantive rather than procedural, the court's independent review may be more appropriately based on the UFMJRA's "public policy" exception to enforcement than on the "due process" exception. See infra notes 248-52 and accompanying text.

237. See supra notes 166-67 and accompanying text. 
Dominican court to "consider and be guided by awards made in similar proceedings" in other jurisdictions when determining the amount of an award, satisfying the third prong on the due process "excessiveness" inquiry. ${ }^{238}$ A Dominican court would seemingly have to comply with the Act and make appropriate findings even where the defendant has not appeared and the plaintiff seeks a default judgment.

A judgment entered pursuant to Dominica's Transnational Act would seem also to comply with the constitutionally mandated procedural safeguards for punitive damages. The Act specifies clear standards for the court to apply in determining whether an award of punitive damages is proper based on the facts presented by the parties, thereby limiting the court's discretion. ${ }^{239}$ Presumably, whether the trial court properly applied these standards and the factors relevant to the trial court's determination of the amount of a punitive damages award can be the subject of review through the Dominican appellate courts. ${ }^{240}$ More importantly, issues regarding the proper application of those standards mandated by the Due Process Clause can be independently reviewed by a court in the United States when the plaintiff seeks to enforce the judgment. ${ }^{241} \mathrm{~A}$ defendant not happy with the resolution of such issues by the U.S. court would then have an opportunity to seek review in the appropriate domestic appellate court, satisfying any due process requirement of appellate review of the punitive damages award. ${ }^{242}$

In addition, because many states impose other, statutory criteria with respect to awarding punitive damages, an enforcement court may review the foreign court's judgment for compliance with these nonconstitutional restrictions. ${ }^{243}$ For example, states typically authorize punitive damages only as to behavior worse than simple negligence, such as for "intentional," "malicious," "outrageous," "bad faith," or "reckless" acts. $^{244}$ The criteria set forth in Dominica's Transnational Act would

238. See supra note 129 and accompanying text.

239. See supra notes 125-26 and accompanying text.

240. See Transnational Act, $\S 4$.

241. See supra notes $168-83$ and accompanying text.

242. See Honda Motor Co. v. Oberg, 512 U.S. 415, 432 (1994) ("Judicial review of the [punitive damages] amount awarded [is] one of the few procedural safeguards which the common law provided against [the] danger . . . that juries will use their verdicts to express biases.").

243. To the extent that these statutory criteria are not mandated by due process, their application by an enforcement court may be more appropriate under the UFMJRA's public policy exception to recognition. See supra and infra notes 228-52 and accompanying text.

244. See Linda L. Schlueter \& Kenneth R. Redden, Punitive Damages $\S 20.1$ (LexisNexis 2005) (collecting states' punitive damages laws); Richard L. Blatt et al., Punitive DamaGES: A State-By-STATE Guide TO LAW AND PRACTICE $\S 3.2$ (Thompson/West 2006) (collecting states' punitive damages laws, grouped by the four categories of conduct). 
seem to satisfy this requirement. ${ }^{245}$ Some states also impose a heightened standard of proof on the fact-finder with respect to punitive damages, usually that punitive damages are available only upon proof by "clear and convincing evidence." ${ }^{246}$ Although the Dominican statute may not explicitly require this heightened standard, the Dominican courts apparently impose it as a matter of common law. ${ }^{247}$

\section{Enforcement of a Foreign Money Judgment Rendered Pursuant to Retaliatory Legislation Designed to Counter Forum Non Conveniens Dismissals: Public Policy Considerations}

Another ground for non-recognition of a foreign judgment under the UFMJRA is that the "cause of action" on which the judgment is based is "repugnant to the public policy" of the state in which the enforcement court sits. ${ }^{248}$ Although this discretionary exception to enforcement defies easy interpretation, most courts give it a narrow construction. ${ }^{249}$ This public policy exception operates only in those unusual cases where the foreign judgment is " "repugnant to fundamental notions of what is decent and just in the State where enforcement is sought.",250 Because the focus is on the "cause of action," the proper inquiry is whether the substantive law applied in the foreign forum is contrary to public policy. ${ }^{251}$ The fact

245. See supra notes 125-26 and accompanying text

246. See, e.g., CAL. CIV. CODE $§ 3294$ (a) (West 2007) (requiring proof by "clear and convincing evidence"); KAN. StaT. ANN. § 60-3702(c) (2007) (same); OHIO REV. CoDE ANN. § 2307.80(A) (West 2007) (same). But see COLO. REV. STAT. § 13-25-127(2) (2007) (requiring proof "beyond a reasonable doubt").

247. See Anderson, supra note 10, at 212. See also Pac. Mut. Life Ins. Co. v. Haslip, 499 U.S. 1, $23 \mathrm{n} .11$ (finding that a higher standard of proof is not a due process requirement).

248. Unif. Foreign MONEY-Judgments RECOGNITION ACt § 4(b)(3), 13, pt. II U.L.A. 39, 59 (2002) (Some states substitute "cause of action" with "claim for relief" in this section).

249. See, e.g., Sw. Livestock \& Trucking Co. v. Ramon, 169 F.3d 317, 321 (5th Cir. 1999) (noting the narrowness of the public policy exception and that the level of contravention of forum law must be high); Ackermann v. Levine, 788 F.2d 830, 841 (2d Cir. 1986) (observing that the standard to satisfy the public policy exception "is high, and infrequently met"); Soc'y of Lloyd's v. Mullin, 255 F. Supp. 2d 468, 475 (E.D. Pa. 2003), aff'd, 96 Fed. Appx. 100, 103 (3d Cir. 2004) (reviewing cases and adopting a "high standard" with respect to the scope of the public policy exception). See also Brand, supra note 147, at 275-76 (noting that the public policy exception seldom has led to denial of enforcement); Silberman, Impact, supra note 147 (noting that outside of the First Amendment area, the public policy exception has not posed a significant barrier to enforcement of foreign judgments).

250. Ackermann, 788 F.2d at 841 (quoting Tahan v. Hodgeson, 662 F.2d 862, 864 (D.C. Cir. 1981). One "classic formulation" is that a judgment is contrary to the public policy of the enforcing state where that judgment "tends clearly to undermine the public interest, the public confidence in the administration of the law, or security for individual rights of personal liberty or of private property ...." Id. (citations omitted).

251. Soc'y of Lloyd's v. Siemon-Netto, 457 F.3d 94, 99-102 (D.C. Cir. 2006); Soc'y of Lloyd's 
that the judgment offends the enforcement state's "public policy does not, in and of itself, permit the[] court to refuse recognition of that judgment." 252

Relying on the public policy exception, U.S. courts have refused to enforce foreign libel judgments where the foreign libel law was repugnant to the free speech values of the First Amendment. ${ }^{253}$ However, when the values involved are less fundamental than the constitutional right of free speech, courts usually enforce foreign judgments even though the foreign cause of action reflects a policy judgment contrary to that of the corresponding domestic law. ${ }^{254}$ For example, U.S. courts have enforced foreign judgments even though they were based on causes of action that would be prohibited, or at least not recognized, in the enforcement forum. ${ }^{255}$

The tort cause of action in our hypothetical Dominican judgment does not violate the public policy of any state. All states authorize tort recovery based on negligence or strict liability. Nearly all states also authorize an award of punitive damages in tort actions, so long as the appropriate substantive standards and constitutionally required

v. Reinhart, 402 F.3d 982, 995 (10th Cir. 2005); Soc'y of Lloyd's v. Ashenden, 233 F.3d 473, 480; Soc'y of Lloyd's v. Turner, 303 F.3d 325, 332-33 (5th Cir. 2002); Mullin, 255 F. Supp. 2d at 47476.

252. Ramon, 169 F.3d at 321. See cases cited supra note 251. But see the recent revision to section 4(c)(3) of the UFMJRA reproduced infra note 258

253. See Sarl Louis Feraud Int'l v. Viewfinder Inc., 406 F. Supp. 2d 274, 281-85 (S.D.N.Y. 2005) (refusing to recognize French money judgment for unauthorized posting of photographs on defendant's website under the public policy exception because incompatible with the First Amendment), vacated on other grounds, 489 F.3d 474 (2d Cir. 2007); see, e.g., Yahoo!, Inc. v. La Ligue Contre le Racisme et L'Antisemitisme, 169 F. Supp. 2d 1181 (N.D. Cal. 2001), rev'd, 379 F.3d 1120 (9th Cir. 2004); Matusevitch v. Telnikoff, 877 F. Supp. 1 (D.D.C. 1995), aff'd, 159 F.3d 636 (D.C. Cir. 1998) (unpublished table decision); Telnikoff v. Matusevitch, 702 A.2d 230 (Md. 1997); Bachchan v. India Abroad Pub’ns, Inc., 585 N.Y.S.2d 661 (N.Y. Sup. Ct. 1992).

254. See, e.g., Turner, 303 F.3d at 332-33 (ruling that the public policy exception is not triggered "simply because the body of foreign law upon which the judgment is based is different from the law of the forum or because the foreign law is more favorable to the judgment creditor than the law of the forum ...."); Ackermann, $788 \mathrm{~F} .2 \mathrm{~d}$ at $843 \mathrm{n} .13$ ("It is is not enough merely that a foreign judgment fails to fulfill domestic practice or policy."). See also authorities cited infra note 255 .

255. E.g., Ramon, 169 F.3d 317 (5th Cir. 1999) (recognizing Mexican judgment on promissory note even though interest charged was usurious under Texas law); Ingersoll Milling Machine Co. v. Granger, 833 F.2d 680 (7th Cir. 1987) (enforcing Belgian judgment awarding prejudgment interest even though inappropriate under Illinois law); Somportex v. Philadelphia Chewing Gum Corp., 453 F.2d 435, 443 (3d Cir. 1971) (enforcing British judgment that included damages for loss of good will and attorney fees even though Pennsylvania law did not allow recovery for loss of good will or attorney fees); Soc'y of Lloyds v. Webb, 156 F. Supp. 2d 632, 643-44 (N.D. Tex. 2001) (recognizing English judgment despite apparent conflict with Texas law that condemns cognovit judgments). See Brand, supra note 147, at 275-76 nn.86-88 (collecting cases); Jay M. Zitter, Construction and Application of Uniform Foreign Money-Judgments Recognition Act, 88 A.L.R. 5th 545, 615-20 (2001 and Supp. 2006) (reviewing cases). 
procedures are followed. ${ }^{256}$ The substantive standards contained in the Dominican statute - that the defendant acted in "bad faith or in reckless disregard of the welfare of others," or persisted in knowingly wrongful conduct - mirrors those employed by many states. ${ }^{257}$

Some enforcement courts may also consider the broader question of whether a foreign judgment is contrary to public policy. ${ }^{258}$ Under that approach, the defendant in our hypothetical could argue that the enforcement of a default judgment which is the result of the defendant's unwillingness to post a pre-appearance bond imposed only on foreign defendants denies such defendants equal protection of law, and therefore violates public policy. ${ }^{259}$ Courts have rejected similar arguments when made by foreign defendants challenging the constitutionality of preanswer bonds in the unlicensed insurer cases. ${ }^{260}$ These courts find a rational basis for the imposition of pre-answer bonds on foreign but not domestic insurers, i.e., to ensure the availability of funds from which a judgment against a foreign insurer may be promptly paid instead of requiring the plaintiff to resort to a distant forum for satisfaction of the judgment. ${ }^{261}$ The same result is likely with respect to the Dominican preappearance bond requirement, which is also imposed for the purpose of

256. See Linda L. Schlueter, Punitive Damages § 20.1 (LexisNexis 2005) (collecting states' punitive damages laws); Richard L. Blatt et al., Punitive Damages: A State-BY-STate Guide TO LAW AND PRACTICE $§ 3.2$ (Thompson/West 2006).

257. See SCHLUETER, supra note 256 (summarizing each state's punitive damages standards); BLATT, supra note 256.

258. Cf. Soc'y of Lloyd's v. Mullin, 255 F. Supp. 2d 468, 477-78 (E.D. Pa. 2003), aff' $d 96$ Fed. Appx. 100 (3d Cir. 2004) (ruling that even under expanded inquiry beyond "cause of action" enforcement of English "judgment" not repugnant to public policy of Pennsylvania). A revised version of section 4(c)(3) of the UFMJRA broadens the focus of the public policy exception by providing that a foreign judgment need not be recognized if "the judgment or the caused of action on which the judgment is based is repugnant to the public policy of this state or of the United States." UNIFORM FOREIGN-COUNTRY MONEY JUDGMENTS RECOGNITION ACT, § 4(c)(3), 13 U.L.A. 11 (Supp. 2007). However, the same stringent text for finding a public policy violation applied by courts interpreting the 1962 Act applies to the revised Act. Id. cmt. 8.

259. The defendant could also argue that the Dominican bond requirement is repugnant to the public policy of the enforcement state regardless of whether that requirement violates either equal protection or due process of law. However, given the discretionary basis of this exception, the stringent nature of the test, and the prevalence of pre-answer bond requirements in the unlicensed foreign insurer context, a court is unlikely to deny recognition based on a non-constitutional source of public policy.

260. See British Int'l Ins. Co. v. Seguros La Republica, S.A., 212 F.3d 138, 143 (2d Cir. 2000); Curiale v. Andra Ins. Co., 667 N.E.2d 313, 317-19 (N.Y. 1996); Trihedron Int'l Assurance v. Superior Court, 267 Cal. Rptr. 418, 422-23 (Cal. Ct. App. 1990). Cf. Lakehead Pipe Line Co. v. Am. Home Assurance Co., 981 F. Supp. 1205, 1215-16 (D. Minn. 1997) (finding rational basis for requiring bond for some, but not all, types of foreign insurers). See Hitchcock \& Biging, supra note 191, at 771 n.17 (reviewing cases).

261. E.g., Curiale, 667 N.E.2d at 319; Trihedron, 267 Cal. Rptr. at 422-23. 
ensuring satisfaction of any judgment rendered against a foreign defendant in a transnational tort action. ${ }^{262}$

The amount of the bond required by Dominica's Transnational Act raises another equal protection issue. ${ }^{263}$ The Act's requirement that the defendant deposit a bond in the amount of "one hundred and forty percent" of the amount awarded in similar proceedings would violate equal protection if that amount is found to be arbitrary and unreasonable. ${ }^{264}$ However, there does appear to be a rational reason for the Act's $140 \%$ figure. The additional $40 \%$ apparently represents security for payment of a judgment that includes an award of costs and attorney fees, in addition to an award of damages. ${ }^{265}$ Under the UFMJRA, the fact that a foreign money judgment includes amounts for attorney fees and costs does not mean that judgment is contrary to the public policy of the enforcement forum. ${ }^{266}$

A default judgment similar to our hypothetical Dominican judgment, but based on Nicaragua's Special Law No. 364, would present two additional public policy issues if enforcement were sought in the United States. First, Special Law No. 364 authorizes damages based on a fixed, statutory amount that defendants might argue is contrary to the requirement that actual damages must be proved. However, such statutory damages are not repugnant to any fundamental public policy in

262. See Anderson, supra note 10 , at 203-04.

263. See McDowell, supra note 78, at 121 (expressing concern about the excessive nature of the Act's bond requirement).

264. See Lindsey v. Normet, 405 U.S. 56 (1972). In Lindsey, the Supreme Court considered the constitutionality of an Oregon statute that required tenants who wished to appeal an eviction judgment to file an undertaking in the amount of twice the rental value of the premises; the landlord is automatically entitled to twice the rents accruing during appeal if the eviction judgment is affirmed. Id. at 75 . This special tenant bond applied in addition to the general appeal bond required of any civil litigant that covers all damages, costs, and disbursements which may be awarded against the appellant on appeal and, if the appellant secures a stay of execution, that also covers the value of the tenant's use of the property during the pendency of the appeal. Id. at 74-78. The court held that this double-bond requirement was unnecessary to assure the landlord payment of accrued rent because that was the purpose of the general appeal bond provisions, and therefore bore no reasonable relationship to any valid state objective. $I d$. at 76-78. Because it arbitrarily discriminated against tenants appealing from an adverse eviction decision, the court concluded that the double-bond requirement violated the Equal Protection Clause. Id. at 79.

265. See Anderson, supra note 10, at 203 ("[T] enacted to take into consideration the satisfaction of an award of damages as well as the associated costs [of litigation]").

266. See, e.g., Somportex Ltd. v. Philadelphia Chewing Gum Corp., 453 F.2d 435, 443 (3d Cir. 1971) (enforcing British judgment including attorney fees even though Pennsylvania law did not allow recovery of attorney fees); Desjardins Ducharme v. Hunnewell, 585 N.E.2d 321, 323-24 (Mass. 1992) (enforcing Canadian judgment for costs awarded based on percentage of amount in issue and not on actual costs). 
cases in which actual damages are difficult to ascertain. ${ }^{267}$ Second, under Special Law No. 364, proof that the plaintiff has been exposed to DBCP pesticide and has been rendered sterile gives rise to an irrebuttable presumption that such sterility was caused by the pesticide. ${ }^{268}$ This irrebuttable presumption as to causation may give rise to a due process concern. ${ }^{269}$

The irrebuttable presumption as to causation in Nicaragua's Special Law No. 364 is, in effect, a rule of substantive law. ${ }^{270}$ Although undoubtedly different from traditional tort law in most jurisdictions in the United States, this difference alone does not mean that Special Law No. 364 is repugnant to the public policy of those jurisdictions. ${ }^{271}$ Given the limited and discretionary nature of the UFMJRA's public policy exception, and the recognition that a foreign law need not be identical to domestic law, a Nicaraguan judgment based on Special Law No. 364's irrebuttable presumption as to causation will likely be enforced by a United States court. ${ }^{272}$

267. See Sarl Louis Feraud Int'l v. Viewfinder Inc., 406 F. Supp. 2d 274, 279-80 (S.D.N.Y. 2005), vacated on other grounds, 489 F.3d 474 (2d Cir. 2007) (ruling French money judgment for intellectual property violation based on fixed, statutory award rather than on proven damages did not offend public policy, and noting that domestic law authorizes such damages when actual damages cannot be ascertained)

268. Special Law No. 364, art. 9.

269. See, e.g., Michael H. v. Gerald D., 491 U.S. 110, 129-30 (1989) (holding statute that created conclusive presumption that child of wife cohabiting with husband was child of the marriage did not violate Due Process Clause); Weinberger v. Salfi, 422 U.S. 749, 784 (1975) (upholding as reasonable under the Due Process Clause a federal law which conclusively denied Social Security benefits to surviving dependents who were related to the wage-earner for less than six months prior to his death); Bruce L. Ackerman, The Conclusive Presumption Shuffle, 125 U. PA. L. REv. 761, 799-808 (1977) (surveying apparent conclusive presumptions that withstand due process scrutiny).

270. See Allentown Mack Sales \& Serv., Inc. v. NLRB, 522 U.S. 359, 378 (1998) (noting that NLRB's irrebuttable presumption is one of those evidentiary presumptions that are in effect substantive rules of law); Michael H., 491 U.S. at 117, 119 (plurality opinion) (observing that conclusive evidentiary presumption in a California statute is the implementation of a substantive rule of law); James J. Duane, The Constitutionality of Irrebuttable Presumptions, 19 REGENT U. L. REV. 149, 160 n.61 (2006) (collecting authorities that conclude irrebuttable presumptions are rules of substantive law).

271. See, e.g., Soc'y of Lloyd's v. Turner, 303 F.3d 325, 332-33 (5th Cir. 2002) (ruling that the public policy exception is not triggered "simply because the body of foreign law upon which the judgment is based is different from the law of the forum or because the foreign law is more favorable to the judgment creditor than the law of the forum"); Ackermann v. Levine, 788 F.2d 830, 843 (2d Cir. 1986) ("It is not enough merely that a foreign judgment fails to fulfill domestic practice or policy.”); Soc'y of Lloyd's v. Mullin, 255 F. Supp. 2d 468, 474-75 (E.D. Pa. 2003), aff'd, 96 Fed. Appx. 100, 103 (3d Cir. 2004) (reviewing cases and ruling that substantive differences between the law of the forum and the law of the nation that rendered the judgment do not automatically trigger the public policy exception). See also authorities cited supra note 255.

272. See supra notes $249-55$ and accompanying text. The irrebuttable presumption in Special Law No. 364 is not unlike one contained in the Black Lung Benefits Act, 30 U.S.C. § 921 et seq. (2000), federal legislation that establishes benefits for a coal miner who is totally disabled by pneumoconiosis ("black lung disease") and survivors where the miner's death was due to 


\section{CONCLUSION}

\section{A. The Impact of Preemptive Jurisdiction Statutes on the Available Alternative Forum Inquiry}

Under the current doctrine of forum non conveniens in effect in most jurisdictions, a motion to dismiss must be denied if no alternative forum is available. Consequently, under the current doctrine, preemptive jurisdiction statutes such as those in effect in many Latin American countries should preclude a forum non conveniens dismissal. Even where a U.S. court is unsure whether another country's statutes preclude jurisdiction, and therefore dismisses based on forum non conveniens, that court should re-assert jurisdiction if it turns out that the courts in the alternative forum are in fact unavailable. Consequently, another country's preemptive jurisdiction statutes should effectively counter a dismissal, at least under the current forum non conveniens doctrine.

Each jurisdiction is free to alter its treatment of the availability prerequisite. Many of the public interest factors relevant to the forum non conveniens determination, such as the financial and administrative burden on the judicial system if the motion is denied, will likely induce courts in some jurisdictions to find a way around another country's blocking statute. One approach would be to treat the availability of an alternative forum as an important factor in the forum non conveniens determination, but not as an absolute prerequisite to dismissal. This approach was taken in Islamic Republic of Iran v. Pahlavi, ${ }^{273}$ where the New York Court of Appeals affirmed a forum non conveniens dismissal despite that lack of an alternative forum where the action could be maintained. $^{274}$ The court explained that proof of the availability of another forum is not required in all cases before dismissal is permitted because "[t]hat would place an undue burden on New York courts forcing them to accept foreign-based actions unrelated to this State merely because a more appropriate forum is unwilling or unable to

pneumoconiosis, to be paid by the claimant's employer mine operator. See Usery v. Turner Elkhorn Mining Co., 428 U.S. 1, 8-10 (1976) (discussing the legislative compensation scheme). The Act declares that when a coal miner is shown by $\mathrm{x}$-ray or other clinical evidence to have pneumoconiosis, "there shall be an irrebuttable presumption that he is totally disabled due to pneumoconiosis or that his death was due to pneumoconiosis, or that at the time of his death he was totally disabled by pneumoconiosis. [sic] as the case may be." 30 U.S.C. $\$ 921(\mathrm{c})(3)$. This irrebuttable presumption was upheld as rational under the Due Process Clause. Usery, 428 U.S. at 20-24.

273. 467 N.E.2d 245 (N.Y. 1984), cert. denied, 469 U.S. 1108 (1985).

274. Id. at $248-50$. 
accept jurisdiction."275 Although this is very much a minority approach today, ${ }^{276}$ courts may well find it more attractive if more countries enact preemptive jurisdiction statutes.

\section{B. The Impact of Retaliatory Legislation on the Use of Forum Non Conveniens as a Defense Tactic}

As discussed previously, two overriding inquiries determine whether retaliatory legislation such as Dominica's and Nicaragua's will have any significant effect on a defendant's use of forum non conveniens in a U.S. court. One is whether the defendant's assets in the country that renders a judgment are sufficient to satisfy the judgment. If, as is frequently the case, the defendant does not have sufficient assets reachable in the rendering country, the second inquiry is whether a judgment based on one of these statutes will be enforced by a U.S. court. If, a subsequent judgment by a court in Dominica or Nicaragua will be enforced by a U.S. court, a defendant may perceive no benefit in moving for a forum non conveniens dismissal, except for the delay inherent in ruling on the motion and in re-filing the action in another country.

Dominica's Transnational Act and Nicaragua's Special Law No. 364 are designed to afford resident plaintiffs many of the procedural and substantive law benefits they would have enjoyed in a U.S. court if their lawsuits had not previously been dismissed based on forum non conveniens. These statutes also remove financial and other barriers to suit, thereby making it very likely that a resident plaintiff will commence an action in his home country after a forum non conveniens dismissal. Because both statutes require defendants to post large bonds sufficient to pay any adverse judgment, U.S. defendants are unlikely to appear in actions governed by either of those laws. Consequently, any such action filed in Dominica or in Nicaragua is likely to result in a default judgment for the plaintiffs.

There is a high likelihood that a default judgment for compensatory damages entered by a Dominican court pursuant to the Transnational Act will be enforced by a U.S. court. If that judgment includes an award of punitive damages, that portion of the judgment will also be enforced if

275. Id. at 249 .

276. Most courts have specifically declined to adopt this approach, and instead view the availability of an alternative forum as a prerequisite to a forum non conveniens dismissal. E.g., Piper Aircraft Co. v. Reyno, 454 U.S. 235, 254-55 n.22 (1981); Binder v. Shepard's, Inc., 133 P.3d 276, 279 (Okla. 2006); Kinney System, Inc. v. Continental Ins. Co., 674 So. 2d 86, 90-91 (Fla. 1996); Stangvik v. Shirley Inc., 819 P.2d 14, 18 n.3 (Cal. 1991); Chambers v. Merrell-Dow Pharmaceuticals, Inc., 519 N.E.2d 370, 373 (Ohio 1988). 
the U.S. court does not view it as penal, and therefore as governed by the UFMJRA, as long as the Dominican court complied with the due process requirements imposed on domestic courts when awarding punitive damages. The standards and procedures set forth in Dominica's Transnational Act appear to satisfy these due process requirements.

A U.S. defendant may perceive no benefit in moving for a forum non conveniens dismissal once that defendant knows that the plaintiff will refile in a Dominican court and that the subsequent Dominican judgment will likely be enforced by a U.S. court. Moreover, there may be several benefits in not filing the motion to dismiss and litigating in the U.S. court. If the defendant has a strong case on the merits, it may prefer to try that case in a U.S. court and not in a Dominican court. ${ }^{277}$ Even if the defendant's case is weak on liability, the defendant may still prefer to have compensatory and punitive damages determined by a U.S. court, which will be more familiar with the relevant standards than a Dominican court. Consequently, in many cases the Transnational Act will likely make the use of forum non conveniens an undesirable defense tactic where Dominica is the alternative forum.

The impact of Nicaragua's Special Law No. 364 on the use of forum non conveniens is more difficult to predict because there are more grounds to challenge the enforcement of a Nicaraguan judgment based on that statute than a Dominican judgment based on the Transnational Act. The imposition of onerous, fixed-amount bonds as a condition to participation in the lawsuit, with no specific statutory mechanism to contest these bonds, raises significant due process issues cognizable under the UFMJRA. The law's irrebuttable presumption regarding causation also raises a substantive due process concern that provides a public policy argument for non-recognition. These concerns make enforcement under the UFMJRA less than certain. However, if the Nicaraguan judgment is the consequence of the plaintiff re-filing his action in a Nicaraguan court after it had been dismissed from a U.S. court based on forum non conveniens, enforcement may be much more likely.

When moving for a forum non conveniens dismissal, the defendant must establish the existence of an adequate alternative forum to hear the

277. The worst case scenario for a defendant with a strong case on the merits would be to obtain a forum non conveniens dismissal and then subsequently not appear in a Dominican action, thereby resulting in a default judgment for the plaintiff. Because under the UFMJRA a defendant is essentially precluded from contesting the merits of the default judgment when the Dominican judgment is sought to be enforced in a U.S. court, the defendant will have waived its right to contest the merits unless it can prove some basis for nonrecognition. See supra notes 157-58 and accompanying text. 
dispute. If a defendant successfully argues that the Nicaraguan courts are adequate to adjudicate a plaintiff's DBCP action, the court may condition a dismissal on the defendant's agreement to pay any final judgment rendered by a Nicaraguan court. Even without this condition, the defendant may be estopped from later challenging a subsequent Nicaraguan judgment as not complying with due process. A defendant who is fully aware of Special Law No. 364's provisions when it argues for the forum non conveniens dismissal should not be permitted later to complain when the plaintiff seeks to enforce the Nicaraguan judgment. Even if permitted to argue for nonrecognition based on due process and public policy grounds, the success of those arguments is by no means guaranteed in light of the pro-enforcement interpretations given these grounds by U.S. courts.

Therefore, like Dominica's Transnational Act, Nicaragua's Special Law No. 364 should have a significant impact on the use of forum non conveniens as a defense tactic. A defendant, knowledgeable of the consequences of a dismissal and a subsequent foreign judgment, will likely prefer to defend a DBCP action in a U.S. court rather than a Nicaraguan court. After all, litigation in the United States will preserve the important causation defense, will permit more individualized challenges to the amount of claimed damages, and will not require a bond as a condition to participation. ${ }^{278}$ This has already occurred in at least one recent DBCP case, where the defendants elected to remain in a California state court rather than seek a forum non conveniens dismissal. ${ }^{279}$ In November 2007, the jury in that case awarded six Nicaraguan farm workers over $\$ 3.2$ million in compensatory damages and, subsequently, an additional $\$ 2.5$ million in punitive damages. ${ }^{280}$

278. The defendants' main defense appears to be that there is a lack of proof that DBCP was the cause of the workers' injuries. T. Christian Miller, A Times Investigation: Plantation Workers Look for Justice in the North, L. A. TIMES, May 27, 2007, at A1.

279. In 2004, several thousand Nicaraguan banana workers allegedly injured by exposure to DBCP filed actions against United States defendants alleging negligence and fraudulent concealment in California courts. Instead of moving for forum non conveniens dismissals, the defendants decided to litigate in a California court. See Miller, Plantation Workers, supra note 278. During July 2007, a jury trial began in the California court to determine the merits of the tort claims brought by twelve of the plaintiffs. See T. Christian Miller, Pesticide Trial Begins Against Dole, Dow, L.A. TIMES, July 20, 2007, at B2; Noaki Schwartz, Banana Workers Suit Opens, Says Pesticide Made Them Sterile, SAN Diego UNION-TRIBUNE, July 9, 2007, at A4.

280. See John Spano, Dole Must Pay Farmworkers \$3.2 Million, L.A. Times, November 6, 2007, at B1 (reporting that a Los Angeles jury awarded $\$ 3.2$ million to six Nicaraguan farmworkers who had sued defendant Dole Food Co.); John Spano, Jury to Consider Punitive Damages Against Dole, L. A. TIMES, November 8, 2007, at B3 (reporting that the jury also awarded the six plaintiffs \$754,000 against co-defendant Dow Chemical Co.); John Spano, Dole Must Pay \$2.5 Million to Farmhands, L.A. TIMES, November 16, 2007, at B3 (reporting that the Los Angeles jury ordered Dole Food Co. to pay five Nicaraguan banana plantation workers \$2.5 million for concealing the 
Several other lawsuits alleging injury due to exposure to DBCP brought on behalf of thousands of plantation workers from other Latin American countries are pending in the California courts. ${ }^{281}$ Even if these DBCP cases do not proceed to trial, they now have an enhanced

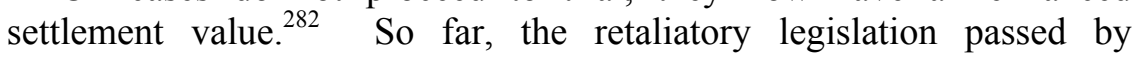
Nicaragua and by the Commonwealth of Dominica is accomplishing those countries' goal of countering forum non conveniens dismissals.

dangers of a pesticide that rendered them unable to have children).

281. John Spano, Dole Must Pay Farmworkers \$3.2 Million, supra note 280.

282. See John Spano, Executive Says "New Dole" Should Not Pay For Misdeeds of "Old Dole," L.A. TIMES, November 15, 2007, at B4 (reporting that the results from the first U.S. trial against Dole could lead both sides to settle the DBCP claims in a global agreement); T. Christian Miller, Pesticide Company Settles Sterility Suit for \$300,000, L.A. TIMES, April 16, 2007, at B3 (reporting that one pesticide company recently settled a DBCP suit by agreeing to pay a total of $\$ 300,000$ to thirteen Nicaraguan workers, with payments ranging from $\$ 2000$ to $\$ 60,000$ per person depending on the injury). 